Portland State University

PDXScholar

\title{
Cultural Compromise of the Wasco and Wishram of the Middle Columbia River: The Effect of Euro- American Technologies and Cultural Values on the Native Americans of the Middle Columbia River
}

Linda Joyce Schreiner-Mahoney

Portland State University

Follow this and additional works at: https://pdxscholar.library.pdx.edu/open_access_etds

Part of the United States History Commons

Let us know how access to this document benefits you.

\section{Recommended Citation}

Schreiner-Mahoney, Linda Joyce, "Cultural Compromise of the Wasco and Wishram of the Middle Columbia River: The Effect of Euro-American Technologies and Cultural Values on the Native Americans of the Middle Columbia River" (1998). Dissertations and Theses. Paper 5804.

https://doi.org/10.15760/etd.7675

This Thesis is brought to you for free and open access. It has been accepted for inclusion in Dissertations and Theses by an authorized administrator of PDXScholar. Please contact us if we can make this document more accessible: pdxscholar@pdx.edu. 


\section{Thesis Approval}

The abstract and thesis of Linda Joyce Schreiner-Mahoney for the Master of Arts in History were presented December 19, 1998, and accepted by the thesis committee and the department .

COMMITTEE APPROVALS:
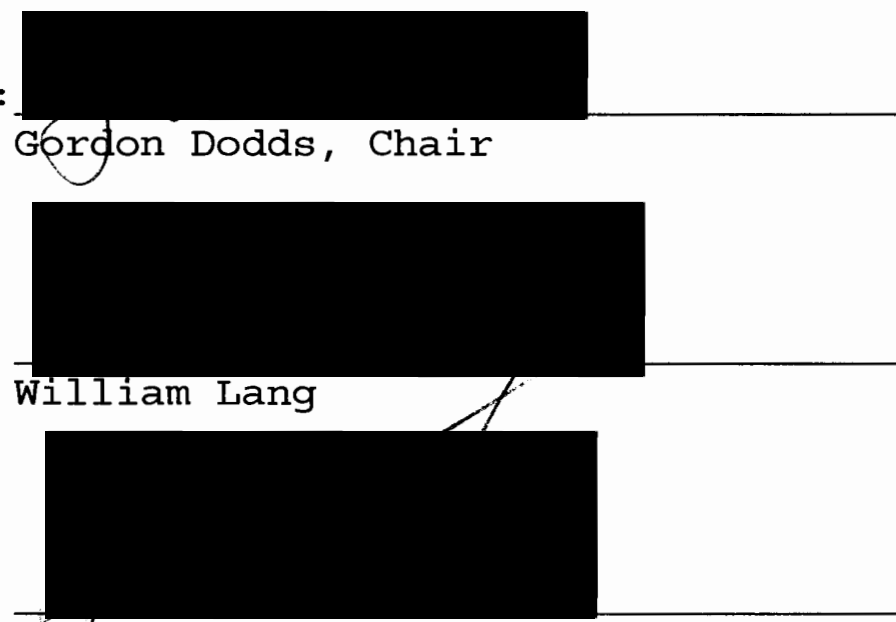

Linda Walton

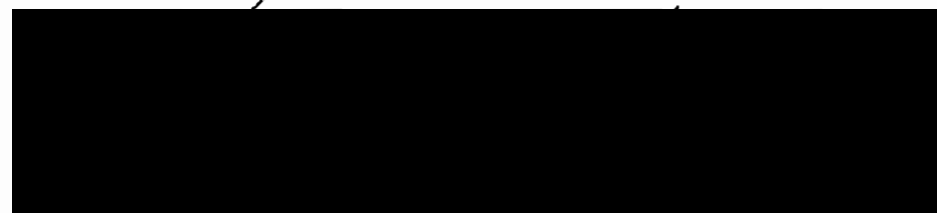

Kerneth Ames

Representative of the office of Graduate studies

DEPARTMENT APPROVAL :

Gordon Dodds, Chair

Department of History 


\section{Abstract}

An abstract of the thesis of Linda Joyce Schreiner-Mahoney for the Master of Arts in History presented December 19, 1997.

Title: Cultural Compromise of the Wasco and Wishram of the Middle Columbia River: The Effect of Euro-American Technologies and Cultural Values on the Native Americans of the Middle Columbia River.

This study examined the Wasco and Wishram's response to the introduction of Euro-American technologies and cultural expectations, and how it affected the natives' culture.

The response of the Wasco and Wishram of the Middle Columbia River to the Euro-Americans in their midst reflects the natives' dynamic culture. These Chinookan speakers were quick to adopt those ideas they perceived as aiding them in the acquisition of material wealth. At the same time, the Wasco and Wishram were resistant to some 
philosophical and cultural changes that traders and missionaries sought to impose.

Difficulties between the two groups were more pronounced when disparate cultural expectations were involved. During trade and social gatherings, the Chinookans expected the whites to reciprocate to their gift-giving in traditional ways, while the whites, ignorant of the social expectations of gift-giving, viewed the natives as avaricious. Euro-American market-derived prices had no place in the Wasco/Wishram's trade sphere when determining the value of native trade goods. Among the traditional trading partners of the Wasco/Wishram, prices were determined through historic exchanges, and the cultural value of those items.

Toward the end of the 18th century the native groups all along the Lower Columbia River suffered tremendous population loss due to the introduction of alien diseases by maritime traders. Two pandemics of smallpox swept through the native population circa 1775 and again in 1801, killing almost 90 percent of the villagers. Malaria 
swept through the region in 1829 killing, in some estimates, upwards of 99 percent of those who survived the smallpox epidemics.

Missionary groups sought to civilize the remaining Chinookans through Christianity starting in the 1830s. Catholic, Methodist and Presbyterian groups sent missionaries to the Pacific Northwest to convert and civilize the natives. The Chinookans viewed the missionaries as sources of spiritual power, providing additional economic avenues and spiritual paths leading to ways to acquire more wealth and prestige for themselves and their families. The Wasco/Wishram failed to recognize they were substituting a new belief system for their native one, and incorporated the new deity and attendant rituals to augment their panoply of spirits. 
CULTURAL COMPROMISE OF THE WASCO AND WISHRAM OF THE MIDDLE COLUMBIA RIVER: THE EFFECT OF EUROAMERICAN TECHNOLOGIES AND CULTURAL VALUES ON THE NATIVE AMERICANS OF THE MIDDLE COLUMBIA RIVER

By

LINDA JOYCE SCHREINER-MAHONEY

A thesis submitted in partial fulfillment of the requirements for the degree of

\section{MASTER OF ARTS}

in

History

Portland State University

1999 
There are many people who helped as I pursued my degree, especially the research and writing of my thesis. First and foremost is David Johnson, who had faith that I could accomplish my goal. Next is my thesis committee comprised of Gordon Dodds, Bill Lang, Linda Walton, and Ken Ames who cajoled, kept me focused, suggested and lent resource material. To these five scholars I owe an immense debt of gratitude.

Special thanks go to Mary Ellen Kirian who regularly watched my daughter so I could take evening classes; George Bergeron who read the innumerable versions of my thesis for content, grammar and logic; Peter Buss my dearest friend and partner who encouraged, supported, listened, nurtured and held my hand when I most needed it; and my daughter Ashleigh who put up with late nights of reading, research in the library, weekends of typing, and missed bedtime stories.

Without the help of these friends and colleagues my thesis could not have been completed. I thank them all for their inspiration, friendship and patience. 
Table of Contents

List of Tables........................

Preface ........................ iv

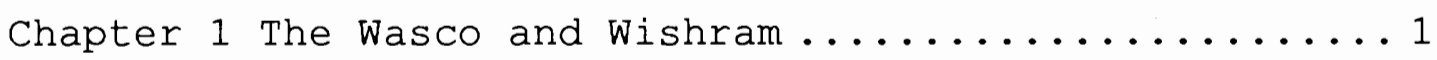

Social Characteristics .................. 7

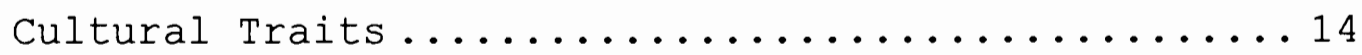

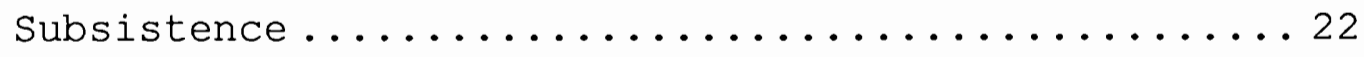

Chapter 2 The Chinookans at Contact............. 35

White Impact on the Chinookans' Culture and Economies

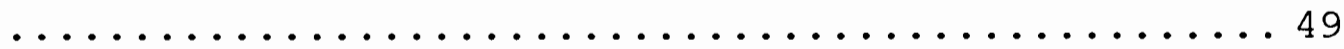

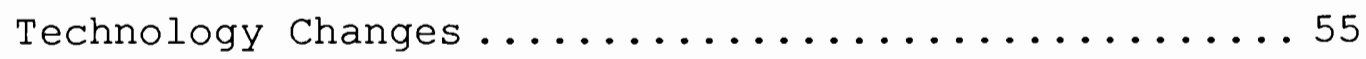

Chapter 3 The Introduction of European Diseases .....67

Native Beliefs in the Origins of Disease.......73

Traditional Native Medical Intervention ........76

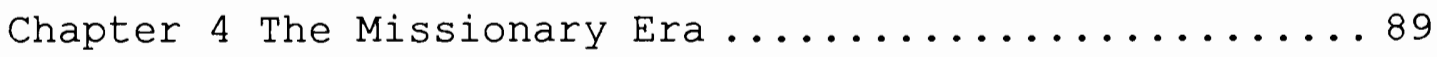

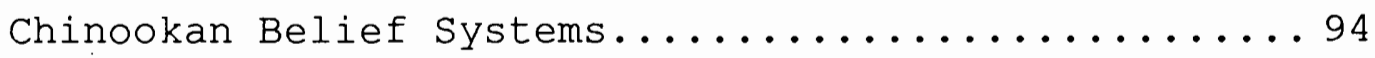

American Religious Attitudes in the $19^{\text {th }}$ Century ... 101

Conflicts between Missionary and Native Societies.. 107

Conclusions ........................... 121

Bibliography ............................ 124 
iii

List of Tables

Lewis and Clark's Estimates of the Native Populations . 33 
Preface

The rich fur resources of the Pacific Northwest stirred the entrepreneurial spirit of 18th century maritime traders. Ships from Russia, England, Spain, and the United States converged to tap this abundance in response to the demands of the fashion-conscious in Chinese and European societies. Yet the traders left more than tangible goods with the natives. In the mid-1770s and again in 1801 smallpox swept through the native population of the Columbia River killing a large percent of the people. The oncepopulous villages of the Lower Columbia River were emptied by diseases introduced by $18^{\text {th }}$ century Euro-American traders. ${ }^{1}$ When Meriwether Lewis and William Clark, leading the Corps of Discovery, arrived at the Columbia River in late 1805, they explored a region that once supported an

\footnotetext{
1 Robert $\mathrm{T}$. Boyd, The Introduction of Infectious Diseases Among the Indians of the Pacific Northwest, 17741874 (Ph.D. Dissertation, University of Washington, 1985), 71. I have drawn heavily from Boyd's work, specifically for information regarding the introduction and spread of smallpox, and malaria; Kenneth M. Ames, "The Archaeology of the Longue Durée: temporal and spatial scale in the evolution of social complexity on the southern Northwest Coast" Antiquity 65 (1991): 973.
} 
estimated 188,000 people, now almost swept clear of inhabitants. ${ }^{2}$

Driven by curiosity, the hope of discovering an inland waterway to the Pacific Ocean, and the hope of claiming the Oregon Territory for the embryonic United States, President Thomas Jefferson instructed his secretary, Meriwether Lewis, to organize a company of men to explore the Missouri River's headwaters and to proceed on to the Pacific. Jefferson recognized that the growing population along the Eastern Seaboard and Piedmont was encroaching on the woodlands natives. The violent clashes that resulted between white homesteaders and the native inhabitants stirred the president to find a solution for both populations. Jefferson had a plan; he wanted to encourage the natives to settle on suitable land and become yeoman farmers. In his address to Congress on January 18, 1803, Jefferson proposed to

- .encourage [the Indians] to abandon hunting, to apply to the raising [of] stock, to agriculture and domestic manufacture, and thereby

${ }^{2}$ Kenneth M. Ames, "The Northwest Coast: Complex Hunter-Gatherers, Ecology, and Social Evolution" Annual Review of Anthropology 23 (1994): 215. 
prove to themselves that less land \& labor will maintain them in this.... ${ }^{3}$

In his next breath, Jefferson introduced his idea to send "[a]n intelligent officer with ten or twelve chosen men" on an expedition to the Pacific Ocean from the Missouri River. Their mission was two-fold; first, to expand the knowledge of the nation in regard to who and what lay beyond the Missouri River. Second was to expand the number of American trading houses among the natives, as an additional inducement to settle by creating a craving in the indigenous peoples for manufactured items. ${ }^{5}$

Six years after the Corps of Discovery wintered on the Oregon coast, John Jacob Astor's Pacific Fur Company built a trading post at the mouth of the Columbia River. Crippled by shipwrecks and stymied by arrogant or unimaginative captains, Astor's dream of riches mined from the Pacific Northwest finally ended with the War of 1812 between Great Britain and the United States. The Pacific Fur Company's Astoria assets were sold to its Canadian rival, the North West Company, which moved into Astor's post in 1813,

\footnotetext{
${ }^{3}$ Donald Jackson, ed., Letters of the Lewis and Clark Expedition with Related Documents, 1783-1854 (Urbana: University of Illinois Press, 1962), 11.

5 Ibid.
} 
renaming the site Fort George. Expanding westward through Canada on the heels of Alexander Mackenzie, Great Britain's Hudson's Bay Company (HBC) acquired Fort George at the mouth of the Columbia River in 1821 in the merger of the two competitors. ${ }^{6}$

The Euro-American fur traders encountered a native society which conferred high status on those men and women who could accumulate items of wealth and redistribute that wealth to the villagers. Possession and redistribution of European manufactured goods was viewed as a means of securing a position among the elite, an avenue of upward mobility from commoner to wealthy leader. The sources of those goods, the traders and trappers, were isolated from other native groups if at all possible, to ensure a monopoly on the acquisition and distribution of prized items. For example, the maneuvering and ploys of Concomly, the Chinook chief at the mouth of the Columbia River, to prevent upriver natives from direct contact with the white traders is a study in duplicity. When the HBC abandoned Fort George and built Fort Vancouver in 1825 the traders unwittingly moved the locus of native power and prestige from the coastal

\footnotetext{
6 Hubert Howe Bancroft, The Works of Hubert Howe Bancroft, vol. 28, History of the Northwest Coast (San Francisco: A.L. Bancroft \& Company, 1884), 444.
} 
peoples to the Multnomahs, the Chinookans inhabiting Sauvie Island and the surrounding lands.

Isolated from daily contact with white traders, the Wasco and Wishram of the Dalles vigorously fended off the intrusion of the $\mathrm{HBC}$, North West Company, and Pacific Fur Company in their territory. The Wasco/Wishram were astute traders who leveraged their physical location to take control of goods moving along the Columbia River from the mouth to the plateau. These Chinookans held a prestigious and commanding position within the native groups that comprised the large trading sphere. The people of the Dalles jealously guarded their position as middlemen along the Columbia River, a position that brought with it wealth and prestige. White traders resorted to intermarriage and sometimes violence to break through the native monopoly on trade.

The Chinookans' experience with the traders was the first step in the natives' move toward dependence on EuroAmerican goods and technologies. Prior to contact their material culture was composed of lithic, bone and antler weapons and tools, yet the Wasco and Wishram quickly adopted

\footnotetext{
Leslie Spier and Edward Sapir, Wishram Ethnography (Seattle: University of Washington Press, 1930) 225; Cole Harris, The Resettlement of British Columbia: Essays on
} 
iron and steel substitutes. It is important to note that this native group enhanced their lithic and bone tool-set with tools of Euro-American manufacture, and did not completely abandon their hand-made tools. Their eagerness to acquire metal items is demonstrated by the fact that the natives would not give up any metal items in trade. On May 9, 1845, Alvan Waller, Methodist Missionary at the Dalles, mentioned that metal fish hooks and awls were his pocket money when contracting services with the Chinookans. ${ }^{8}$

The Missionary Society of the Methodist Episcopal Church sent the Reverend Jason Lee to the Oregon Country in 1834. Lee was entrusted with stamping out the 'heathen and idolatrous' practices of the 'benighted savages.' Hoping to civilize the natives through Christianity, Lee and his colleagues worked to spread the Gospel among the native peoples of the lower Willamette valley, and the Dalles. Much to their consternation the Methodist missionaries were met with indifference from the Chinookans, then competition from the Catholic priests who followed in 1840. The Catholic mission successfully positioned itself in the

Colonialism and Geographical Change (Vancouver: University of British Columbia, 1997), 50. 
Willamette Valley and along the Columbia River, offering spiritual comfort to the retired HBC French Canadian voyageurs in addition to the officers and staff stationed at Fort Vancouver. Catholic missions to the natives were more successful since the priests could move freely with the seasonal movements of the Chinookans. The support of the Chief Factor at Fort Vancouver was significant as well. In contrast, the Protestant groups were tied to their missions and their families. Internal strife amongst the Methodist missionaries in Oregon diverted their attention from their original goal. Finding the language barriers and native apathy extremely difficult to overcome, the Methodists finally resigned themselves to focusing on the white population, incorporating a few native children into the mission schools.

In the meantime, the missionaries' reports to the East were printed in secular periodicals exciting the imagination of men and women who sought a fresh beginning. Encouraged by glowing reports of fertile soil, a salubrious climate, and a seemingly unpopulated countryside, thousands of Americans determined to emigrate to the oregon Country.

${ }^{8}$ Alvan F. Waller diary extract, May 23, 1842, Oregon Historical Society Manuscript Library, MSS 1210, fol. 11 
The population I studied was the Chinookans residing close to the Dalles (the Wasco and Wishram). This group was part of an extensive trade network that was inextricably tied to the river for subsistence. As a result of EuroAmerican contact and subsequent emigration, the Chinookans of the Lower Columbia River experienced three crises in the first half of the nineteenth century. The first was loss of population due to disease; the second, stress on their culture due to trader and missionary interference; and the third was the loss of land due to white settlement. I will discuss the mechanisms that altered this indigenous culture, the intersections of white and native philosophical thought, how native society reacted to the influx of disease, and the moral dilemmas the Chinookans faced when exhorted by the missionaries to change their lifestyle. The sequestering of indigenous peoples on reservation land has been extensively covered in the literature and is assumed to be familiar to the reader.

In order to answer the questions I have posed, I examined primary source materials written by Gabriel Franchère, James Swan, Alexander Ross, George Gibbs, Alvan Waller, Henry Perkins, François Blanchet, and Modeste 
Demers, in addition to the ethnographic/ethnohistoric data compiled by Franz Boas, Verne Ray, Edward Sapir, Leslie Spier, James Teit, Robert Boyd, Eugene Hunn, and others, that has a direct bearing on the question regarding the progression from a strong viable culture to one struggling to comprehend the loss of life, and changes in their economic base brought about by their contact with whites. However, when using ethnographic literature collected at the turn of the nineteenth century (Boas in late 1880s, early 1890s, Ray in 1920s and 1930s) the reader should be aware that in most cases the informants had lived on reservations in close association with other native cultures for 40 years or more. This is not to say the oral traditions that native informants had to offer are not valuable as research material, but should be weighed carefully and critically. Such oral histories give us a clear sense of the culture at the time the stories were collected.

Missionary sources that recount the attitudes and reactions of the natives encountered are, in most instances, full of interpretation, either through self-delusion by the writer, or in an effort to justify their mission to the organization that sent them (for example, Jason Lee's glowing reports to the Board of Foreign Missions.) In either instance the reader should be aware of the cultural 
and social biases that are an undercurrent throughout the missionary documents.

I have used contemporary terminology for prehistoric dates noted as BP which denotes 'before present', the terminal date being $1950 \mathrm{AD}$ when radiocarbon dating technology came into usage. Although there is no consensus regarding the appellation to use to describe the aboriginal inhabitants of North America, I have chosen to use the terms Native Americans, Chinookans, and Natives, avoiding the term 'Indian' except when used in direct quotations. This nomenclature currently has wider usage among Native Americans and non-Native American groups. 
The Wasco and Wishram:

The Chinookans of the Dalles

This chapter will introduce the native populations of the lower Columbia River in preparation for the remainder of my thesis. It is in the context of the Chinookans' pre-contact culture by which their reactions to the introduction of alien material goods and ideas should be weighed. Occasionally I will compare the Wasco and Wishram to the Multnomahs of Sauvie Island. Although very little has been written about the Multnomah, it can be assumed that their culture was similar to the wasco and Wishram at the Dalles, and the Chinook at the mouth of the Columbia River, with small, localized differences. I chose to use the Multnomahs as a comparison because of their close proximity of Fort Vancouver, the Hudson's Bay Company trading post situated on the north bank of the Columbia River. While focusing primarily on the Wasco/Wishram, I examined differential responses between 
the two groups of Chinookans to determine the effect of ideological influence introduced by the Euro-American cultures.

Archaeological evidence indicates that the region surrounding the Dalles was occupied as early as 8,000 BP. The Wasco and Wishram at the Dalles had settled in the region earlier than $3,000 \mathrm{BP}$. The archaeological record indicates that there were people, perhaps the precursors of the Multnomahs, also known historically as the wapato who lived on Sauvie Island, in the region of Vancouver Lake as early as $3500 \mathrm{BP}$. Yet this date may obscure the earliest indication of the Multnomah's presence in the area. Due to rising sea levels which stabilized circa 3000 BP, earlier sites may be buried under alluvium or the waters of the Columbia River. ${ }^{9}$

"Chinook," or Tsi-nuk, was originally the name of a single village on the north shore of the mouth of the

\footnotetext{
Kenneth M. Ames, Done E. Dumond, Gerry R. Galm, Rick Minor, "The Archaeology of the Southern Columbia Plateau" MSS, n.d., 6; Ames, Northwest Coast", 221; Richard M. Pettigrew, "Prehistory of the Lower Columbia and Willamette Valley" Handbook of North American Indians (Washington: Smithsonian Institutions, 1990) vol. 7, 519.
} 
Columbia, but the term was extended historically to the speakers of all Chinookan languages. "Chinook," as a tribal name, is restricted to the speakers of the Chinook language on the north side of the Columbia; the rest of the natives residing along the Columbia River are called Chinookans. "Chinookan" is a generic term used to identify speakers of languages related to Chinook. ${ }^{10}$

At contact the Chinookan people occupied the lower Columbia River in villages clustered along the river from its mouth east to the Dalles, and extending along the coast from Willapa Bay in Washington to Oregon's Tillamook Head. Chinookan villages tended to be situated near mouths of tributary streams, sloughs, surrounding bays, near ready access to the waterways, and especially around prime fishing areas such as the Dalles, the Cascades, and Willamette Falls. The Multnomahs were concentrated on the Columbia slough, primarily on the south side of the river.

\footnotetext{
10 Frederick W. Hodge, ed., Handbook of American

Indians North of Mexico, vol. 1 (Washington: Government Printing Office, 1907), 273; Michael Silverstein, "Chinookans of the Lower Columbia" in The Northwest Coast: Handbook of North American Indians, vol. 7 (Washington, D.C.: Smithsonian Institution 1990), 533-535.
} 
A majority of their villages were located on sauvie Island, (known historically as Wapato Island, Multnomah Island, or Wyeth Island.) The Multnomahs may have spoken an Upper Chinookan dialect that was mutually intelligible to the natives on either side of them, the Cathlamet to the west and the Clackamas to the east. The Wasco and Wishram at the Dalles were also considered Chinookans, although they spoke Upper Chinook, or Kiksht. ${ }^{11}$ See the discussion below for details on the language.

There is a distinction between the Dalles and the modern city of The Dalles. The former had been called the Long Narrows by Lewis and Clark, and La Dalles by French trappers. It is approximately three miles east of the modern city of The Dalles. The Wasco and Wishram lived nearer the Dalles and that is the area to which I will consistently refer.

\footnotetext{
Becky Saleeby and Richard M. Pettigrew, "Seasonality of Occupation of Ethnohistorically-Documented Villages of the Lower Columbia River" in Robert E. Greengo, ed., Prehistoric Places on the Southern Northwest Coast (Seattle: University of Washington, 1983), 169; Waller MSS, fol. 11; Lewis A. McArthur, Oregon Geographic Names, sixth ed., (Portland: OHS Press, 1992), 743-4; Silverstein, "Chinookans of the Lower Columbia", 534-5.
} 
The Chinookan language evolved as a family of the Penutian phylum, bifurcating into Lower (Coastal) Chinookan and Upper (River) Chinookan. Lower Chinookan was spoken on the north and south shores of the mouth of the Columbia River, and northward to Willapa Bay. Chinook jargon, a composite language used primarily for trading, was based on Lower Chinookan. The jargon most likely arose on the Columbia River before the advent of European exploration, and rapidly spread over the southern portion of the Northwest, from the Alaskan panhandle down the coast to northern California, and reaching deeply into the Columbia Plateau. It was largely adopted within the region bounded by the eastern border of oregon and Washington, extending to the Paiutes of Nevada. There continues to be some discussion regarding the first use of Chinook jargon. While some researchers claim it evolved through interaction with white traders, I agree with those who assert jargon was in use prior to contact because the extensive trading spheres utilized by many different peoples along the Pacific Northwest coast would promote a 
jargon to facilitate economic intercourse. Lewis and Clark commented on the similarity of words they encountered in distinct villages as they traveled. Trade among the Tillamook, Clatsop, Sahaptin, and other indigenous people was carried on among those who spoke mutually unintelligible languages which fostered the development of jargon. Chinook jargon also picked up additional words from English and French through contact with traders and explorers, as well as from indigenous languages of the area. Used by most fur traders, many missionaries, and some early settlers, Chinook jargon has contributed words to the English vernacular, including "potlatch" (give; ceremony at which gifts are given), "tyee" (chief), "eulachon" (name of a fish), and "tillikum" (friend, people). ${ }^{12}$

\footnotetext{
Laurence C. Thompson and M. Dale Kinkade, "Languages" Handbook of North American Indians vol. 7 (Washington, D.C.: Smithsonian Institutions, 1990) 41, 50; Gallick Mallery, "Disuse of Sign Language" First Annual Report of the Bureau of Ethnology to the Secretary of the Smithsonian Institution, 1879-89 (Washington, D.C.: Government Printing Office, 1880), 313; James Mooney, "Myths of the Cherokee" Nineteenth Annual Report of the Bureau of Ethnology to the Secretary of the Smithsonian
} 
Social Characteristics

The fundamental unit of the Chinookans' village was the household. The permanent village usually consisted of more than one household. Kinship was traced bilaterally with wives coming from unrelated families in separate villages. Most likely, heads of households differed in status from one another, with the village chief having the most social prestige. The core population consisted of males who were related to each other patrilineally, together with their wives and children, and their slaves. It is possible that in-laws, orphans and occasional hangers-on also formed part of larger households. Thus an extended family formed the basis of the village and incorporated other villages and their regional resources through marriage. Their spatial position within the house was determined by social rank. Higher ranking members resided at the rear of the house, lower ranking toward the front, while slaves huddled by the front door. Household

Institution, 1879-89 (Washington, D.C.: Government Printing Office, 1880), 187. 
size varied from the Dalles to the Coast. Three or four families is the most frequent estimate of household size, corroborated by William Clark. ${ }^{13}$

Archaeological evidence suggests that villages were clustered around major fishing sites. This is certainly supported by the location of the Wasco and Wishram at the Dalles, and the Multnomahs at the mouth of the willamette on Sauvie Island. In the case of the last group of natives, wapato (the tuber of the Arrowhead plant, Sagitarria latifolia) was a prime food resource that was abundant on Sauvie Island. Another source of food was acorns which, when leached of their tannins, were palatable. However, the Chinookans had a particular method by which they prepared acorns. Paul Kane made this observation in 1846 .

There is another article of food made use of amongst . . . the Chinook Indian . . . it is however, regarded only as a luxury and not as a general article of food. The whites have given

\footnotetext{
13 Yvonne Hajda, "Regional Social Organization in the Greater Lower Columbia, 1792-1830" (Ph.D. dissertation, University of Washington, 1984), 77, 155, 170; Ames, "The Northwest Coast", 211; Gary E. Moulton, ed., The Journals of the Lewis \& Clark Expedition, vol. 6 (Lincoln: University of Nebraska Press, 1990), 219.
} 
it the name of Chinook Olives, and it is prepared as follows: About a bushel of acorns is placed in a hole. . close to the entrance of the lodge or hut, and covered over with a thin layer of grass, on top of which is laid about half a foot of earth; every member of the family henceforth regards this hole as the special place of deposit for their urine, which is on no occasion to be diverted from its legitimate receptacle. . .

The Wasco and Wishram also prepared acorns by pitroasting, then steaming the nuts. The acorns were then mixed with blue mud and aromatic seeds and stored in a pit close to the river. Acorns were primarily used as a snack food, not as a staple. Lewis and Clark noted that acorns of the white oak, both roasted and raw, were used as food. ${ }^{14}$

There were three distinctions in the Chinookan class structure: the elite who possessed rank and wealth, the

\footnotetext{
${ }^{14}$ Hajda, "Regional Social Organization", 89; Paul Kane, Incidents of Travel on the North-West Coast, Vancouver's Island, Oregon, \&C., \&C., (read before the Canadian Institute in Toronto, March 14, 1855), 33; Spier and Sapir, Wishram Ethnography, 185; Jarold Ramsey, ed., Coyote Was Going There: Indian Literature of the Oregon Country, (Seattle: University of Washington Press, 1980), 58-90; Moulton, The Journals, vol. 5, 317.
} 
free commoners with little wealth, and the slaves. Chinookan culture was a mix of ascribed and achieved social status in which an individual either inherited elite status (ascribed), or acquired elite status by accumulation and distribution of wealth (achieved). The elite class was responsible not only for the management of food resources, but also for the cultivation of individuals who would then inherit the privilege to control particular territories. The redistribution of resources within the village group, whether trade items or food, was a significant political development and resulted in a hierarchical access to resources. The elites' power and authority were dependent upon their ability to attract followers and retain their loyalty through the control, acquisition and redistribution of resources. ${ }^{15}$

Powerful leaders dominated an individual village; in some cases, by reason of superior qualities, a leader might extend his or her influence over several neighboring

\footnotetext{
15 Ames, "The Northwest Coast", 221; Washington Irving, Astoria (Portland: Binfords and Mort, 1950), 67; Hajda, "Regional Social Organization", 165, 173-176, passim.
} 
villages. Frequently these were individuals who possessed exceptional leadership and entrepreneurial skills. Disputes arising within the village or even outside the village would be brought before the chief to be mediated. This was to prevent a feud from erupting that might have resulted in numerous deaths. ${ }^{16}$

Gender roles appear to have been clearly defined: Slave raids and local conflicts were pursued by men. Trade was carried on by both men and women. Shamans were both men and women, and goods produced or acquired by men such as canoes, fish, and furs, were valued more highly than the mats, baskets, and dried foods produced by women. ${ }^{17}$

Generally speaking, the Chinookans maintained permanent residences along the Columbia River which were

\footnotetext{
Brian Fagan, Ancient North America: The Archaeology of a Continent (New York: Thames and Hudson, Inc., 1991), 202; Spier and Sapir, Wishram Ethnography, 214; Hajda, "Regional Social Organization", 202, 206. 17 Hajda, "Regional Social Organization", 172; Alexander Ross, Adventures of the First settlers on the Oregon, or Columbia River, (1904; reprint, with a foreword
} 
augmented with temporary hunting and fishing camps at various times of the year. It is important to note that the Multnomahs and the Wasco/Wishram lived in dissimilar environments. The Multnomahs lived in the more lush Portland Basin with a greater variety of resources. The diversity and abundance of food resources could support a larger population. This is supported by Lewis and Clark's estimates of residents on and around Sauvie Island (see table 1.) The alluvial confluence of the willamette and Columbia rivers nurtured riparian habitats, grasslands, and fir, oak, filbert, hemlock, and deciduous forests in which deer, bear, water fowl, and vegetable food resources (berries; roots, especially wapato; fruits; nuts; and shoots) were found in abundance. Five salmon species (Oncorhynchus tschawytscha, o. nerka, o. kisutch, 0 . gorbuscha, and 0 . keta), sturgeon (Acipenser transmontanus), and smelt (Sprinchus thaleichthys) were important food sources as well. ${ }^{18}$

by James P. Ronda, Lincoln: University of Nebraska Press, 1986), 92 .

18 Rick Minor "Aboriginal Settlement and Subsistence at the Mouth of the Columbia River", (Ph.D. diss., 
The Wasco/Wishram resided east of the Cascade Mountains in the high desert. The regional environment was drier with more extreme temperature differences. There were fewer vegetable resources available to the natives which is reflected in the population estimates by Lewis and Clark. Fir (Pinus sp.) and juniper (Juniperus) provided cover for wildlife such as deer (Odocoileus spp.) and elk (Cervus elephus), bear (Ursus spp), and small mammals. Salmon figured significantly not only in the Wasco/Wishram's diet, but in their economy. ${ }^{19}$

The permanence of the settlements may also reflect the energy investment required to build the plank houses in which the Chinookans lived. Archaeological evidence points to the existence of plank houses as a standard house type by 3000 BP. Winter villages consisted of permanent structures, while summer camps were constructed

University of Oregon, 1985), 78-82, passim; Hajda, "Regional Social Organization", 51, 91-95, passim; Daniel Lee and Joseph H. Frost, Ten Years in Oregon (New York: J. Collord, Printer, 1844), 163; Saleeby and Pettigrew, "Seasonality of Occupation", 173; Patrick Gass, Gass's Journal of the Lewis and Clark Expedition (Chicago: A.C. McClury, 1904), 169. 
of light frameworks covered with tule or cattail mats for temporary shelter, easily assembled and moved as necessary. ${ }^{20}$

At the Dalles, the Wishram spent the winter in Nixlu'idix, which means "trading place" in Kiksht, on the north side of the Columbia, and in temporary camps closer to the river during the summer. The residence patterns of the Multnomahs at Sauvie Island are poorly documented. However, it is safe to assume that the island was abandoned during the spring when the Columbia River inundated the island with spring melt. ${ }^{21}$

\section{Cultural Traits}

The Chinookan people lived in villages of large rectangular houses. Evidence along the Columbia River indicates these houses were semi-subterranean with a wood

\footnotetext{
${ }^{19}$ Hajda, "Regional Social Organization", 55; Ames, "The Northwest Coast", 217.

20 Hajda, "Regional Social Organization", 77, 170; Ames, "The Northwest Coast", 220; ___, "Archaeology of the Longue Durée", 939, 942; Silverstein, "Chinookans of the Lower Columbia", 538. 172 .

${ }^{21}$ Saleeby and Pettigrew, "Seasonality of Occupation",
} 
superstructure. Construction of a plank house was no frivolous undertaking. For example, there were as many as 55,000 board feet of lumber used to erect the Meier site plank house on Sauvie Island. There was some variability in the size of plank houses along the Columbia River although a mean range was 4.5 to 9 meters in width and 6 to 15 meters in length. The houses were constructed of cedar planks that were lashed to a substantial frame of posts and beams with withe (withe is a flexible twig of willow, or the fiber stripped from beneath the bark of a cedar tree), or fastened with pegs. ${ }^{22}$

William Clark, pausing among the Wishram in October 1805, described their houses as follows:

[T] hose houses are about the Sam Shape Size and form 20 feet <Square> wide and 30 feet long with one Dore raised 18 Inches above ground, <which> they are 391/2 inches high \& 14 wide, forming in a half Circle above those houses were sunk into the earth Six feet, the roofs of them

\footnotetext{
22 Joan M. Vastokas, Architecture of the Northwest Coast Indians of America (Ph.D. diss, Columbia University, Fine Arts, 1966), 67; Kenneth M. Ames, et al. "Household Archaeology of a Southern Northwest Coast Plank House" in Journal of Field Archaeology 19(3), 277; Gabriel Franchère, Narrative of a Voyage to the Northwest Coast of America. . . Reuben G. Thwaites, ed., (Cleveland: The Arthur H. Clark Co, 1904), 328.
} 
was Supported by a ridge pole resting on three Strong pieces of split timber thro' one of which the dore was cut con which> that and the walls <which> the top of which was just above ground Suported a certain number of spars which are Covered with the Bark of the white Ceadar, or Arber Vitea; and the whole attached and secured by the fibers of the Cedar. the eaves at or near the earth, the gable ends and side walls are Secured with split boards which is seported on iner side with strong pieces of timber under the eves \&C. to keep those pieces errect \& the earth from without pressing in the boards, suported by Strong posts at the Corners to which thoe poles were attached to give aditional strength, Small openings were left [NB: in the roof] above the ground, for the purpose, as I conjectured, of descharging Their arrows at a besiegeing enimey; Light is admited Thro an opening at top which also Serves for the Smoke to pass through. one half of those houses is apropriated for the Storeing away Dried \& pounded fish which is the principal food The other part next the dore is the part occupied by the nativs who have beds raised on either Side, with a fire place in the center of the space each house appeared to be occupied by about three families; ${ }^{23}$

In archaeological excavations of Chinookan plank houses, corner post holes have been measured up to $50 \mathrm{~cm}$. in diameter. The roof was of two styles; shed or gable roof, gable being more common in this area. Families within the household would remove the planking from the frame and take it to their alternate residence when it was time to 
move. Lining the inside of the plank house were benches made either from dirt or planks. In some cases plank benches covered storage areas. These benches were used for sleeping and other activities. Running down both sides of the house was an aisle that was either dirt (sometimes covered with mats), or planks. In Chinookan plank houses, the floors were usually earthen, covered with beach sand, crushed shell or fine gravel. The floors were swept and washed, compacting the dirt which eventually formed laminae or thin layers. Interior posts were carved and painted, and the oval entrance to the house also was decorated. ${ }^{24}$

Lewis and Clark noted in their journals that the Chinookans traded slaves with other native groups on the Columbia. The Chinookans were suppliers of slaves for the interior peoples. Slaves, consisting primarily of boys and girls, with some adults among them, were very numerous among the lower Columbia natives. The stigma of having

\footnotetext{
Hajda, "Regional Social Organization", 141; Ames, "Household Archaeology", 278; Vastokas, "Architectures",
} 
been enslaved prevented many from returning to their own villages should they succeed in escaping. Among the Wasco and Wishram, a captured runaway slave was burned on the bottom of the feet to impress on him or her not to attempt escape again. ${ }^{25}$

Slaves served an economic purpose in addition to their importance as a labor force, although debate continues as to whether slaves were more important as a labor force or a symbol of wealth. Slaves were viewed as objects of wealth just as the háikwa shells, blankets, or beads of the high status individuals within Chinookan society. As a source of labor slaves assumed both male and female traditional work tasks. Slaves were taken either in slaving raids or in warfare, and were traded for various items. As a commodity, slaves were also used in the ritual gift exchange of marriage partners among the Wishram, or to pay gambling debts. During the early

69.

25 Donald Mitchell, "Predatory Warfare, Social Status, and the North Pacific Slave Trade" Ethnology, 23 (1): 45; Spier and Sapir, Wishram Ethnography, 221, 223; Edward Sapir, Wishram Texts, vol. 2 (Leyden, Holland: E.J. Brill, 1909), 222. 
settlement years, whites in the willamette Valley also bought slaves from the Chinookans to use as farmhands. ${ }^{26}$

Contrary to popular belief wives were not purchased among the Columbia River natives. Instead a highly ritualized ceremony took place between the two families. Marriage ceremonies varied slightly among the different villages. Gabriel Franchère, a French Canadian trapper in the employ of John Astor's Pacific Fur Company, traveled extensively along the Columbia in the years 1811 through 1814 and was a keen observer of the Chinookans and their environment. While trading along the river he observed the exchange of wedding presents between a man's family and that of his intended wife's family. Gifts were distributed to all those who were in attendance, related or not. Depending on the status of the man's family the gifts may have consisted of slaves, beads, háikwa (dentalia) shells, clothing, a canoe, robes, blankets,

${ }^{26}$ Robert Ruby and John A. Brown, The Chinook Indians: Traders of the Lower Columbia River (Norman: University of Oklahoma Press, 1976), 130.; Franchère, Narrative of a 
baskets, and mats. The woman's family would distribute gifts according to their means to the man's family. The wedding party would visit each set of parents to exchange gifts within the space of a few days or weeks. After a year, the visiting was repeated. Men who could afford more than one wife usually married more frequently. This allowed a family to extend kinship ties to other resource areas. This is significant when the women would return to their maternal villages during the summer months to collect roots, berries, and grasses for mats. The dispersal of plural wives to different resource-gathering areas permitted a greater accumulation of foodstuffs for the winter months, and allowed the husband to distribute part of his surplus food as wealth during the winter ceremonies. This distribution of surplus food conferred prestige on the man and his family. ${ }^{27}$

Voyage, 324 ; Silverstein, "Chinookans of the Lower Columbia", 542 .

27 Franchère, Narrative of a Voyage, 331-32; Cox, The Columbia River, 172; Hajda, Regional Social Organization, 176-177, 181. 
Like their neighbors east and west along the Columbia, both the Multnomahs and Wasco/Wishram had similar burial practices but with regional variations. The Multnomah wrapped the corpse in mats and dressed skins, then lay the body in a canoe. At the Dalles, the body was wrapped in mats and skins, then placed in a wooden vault built on an island. The Corps of Discovery observed the burial practices of the Chilluckittequaws, a village of Chinookans just below the Dalles. They described burial vaults approximately eight feet square and six feet tall, made of cedar boards, the walls and door of which were decorated by carvings and paint. The members of the Corps of Discovery also described the presence of wooden images which they believed were intended as likenesses of the deceased. Chinookans in the vicinity of Fort Vancouver entombed their dead in elaborately decorated canoes which were then elevated on posts, or placed in tree branches. Items that would prove to be useful in the deceased's afterlife were attached to the branches of the tree, or laid beside the body in the canoe. Wooden bowls, kettles, bows and arrows, ornaments, baskets of food, and favorite 
items were all included as part of the burial accouterments. Those items that could hold water were punctured to prevent the less scrupulous from taking them. Alternatively the remains were placed in carved boxes which were then elevated. An elder with special powers was called upon to prepare the body for burial. Family members, and sometimes slaves, cut their hair short (to the ears). They then visited the sweat lodge five times to cleanse themselves. Wealthy families would re-wrap the corpse with a new robe and mats after a year had passed. ${ }^{28}$

\section{Subsistence}

Subsistence along the Columbia River was centered on the procurement and processing of salmon. Spring and early summer fish resources were procured and dried for storage, and, as a natural extension, late summer and fall food resources were also stored. Clark's entry in his Hajda, "Regional Social Organization", 139-40, passim; Moulton, Journals, vol. 5, 358-9; Silverstein, "Chinookans of the Lower Columbia", 543. Cox, The Columbia River, 77, 179. 
journal dated October 19, 1805, recounted the Chinookans fishing and drying fish in "great quantities" on scaffolds near the river. James Swan, a settler on the Columbia in the mid-nineteenth century, described how the women split the salmon down the back, thinly sliced the meat, then dried it in the smoke of the hearth. When completely cured, it was packed in baskets for storage. ${ }^{29}$

Terrestrial resources included deer, wapiti (elk), and medium size mammals. Vegetable resources included berries, ferns, nuts, roots, and fresh sprouts. For a more complete discussion of the vegetable and animal resources see Wayne Suttles' "Environment", in Handbook of North American Indians, volume 7.

It is vital to understand the nature of the subsistence activities carried out at each settlement type throughout the course of the year. Each settlement fell within the ordinary and predictable round of activities of the Chinookan people. The annual subsistence cycle as Coast; or, Three Years at Shoalwater Bay (1857, reprinted 
practiced by the Chinookans depended upon the interplay of a number of factors, including available resources, seasonality, exploitative technology, geography and weather. Together, the annual subsistence cycle and the resultant settlement pattern combine to form the subsistence-settlement system that characterized their society. The Columbia River region exhibits a large range of environmental diversity in which fishing, shellfish collecting, marine and terrestrial mammal hunting and some plant gathering were significant. ${ }^{30}$

Archaeological studies of the Chinookan peoples' village sites along the Columbia River have helped to explain many aspects of their material culture, and have led to inferences regarding their society prior to contact. The largest and most remarkable item contained within the complex of artifacts of the Chinookan people was the plank house (see discussion in cultural Traits, above) .

Seattle: University of Washington, 1972), 111.

30 Minor, Aboriginal settlement, 18. 
In examining data collected during excavation in the Portland Basin, Richard Pettigrew found a rich cultural assemblage that consisted of chipped stone tools including bifacial projectile points, knives, scrapers, atlatl weights, gravers, choppers, cobble flake scrapers; pecked stone tools such as mauls, chopper/anvils, small bowl, mortars/pestles, and net weights. There were also items made from bone and antler such as bilaterally-barbed projectile points, composite toggling harpoon valves, awls, chisels, wedges, drills, and pins. Occupation of the Sauvie Island sites was distinct from other Chinookan villages along the Columbia River. Ethnohistoric research has determined that villages on sauvie Island were occupied approximately year round, being abandoned only when threatened by rising water at the river's edge. This is significant in the basic model of sedentism as a greater degree of sedentism is suggested in this than has been previously acknowledged. Such an anomaly suggests that settlement patterns may not have been uniform among all of the native peoples of the Lower Columbia. ${ }^{31}$

31 Pettigrew, "Prehistory of the Lower Columbia", 518; 
As early as 2500 BP, the Chinookans had an extensive exchange network through which items were traded. Dentalia (háikwa) shell beads, olivella shell beads, bird bone beads, stone beads, oils, furs, skins, salmon, camas flour and bulbs, as well as reed mats have been either recovered archaeologically or reported ethnographically along the Columbia River. In addition to tangible goods, cultural traits and ideas were passed along these extensive trade networks. Ethnographically, this area is considered one in which the basic Northwest Coast cultural pattern adapted certain cultural traits derived from the Columbia Plateau. The adopted Plateau traits included the construction of mat lodges as temporary dwellings, coiled basketry, truncated conical basketry caps for women, the small steam sweat lodge, and use of long nets for fishing and hunting. The Chinookans had adopted so many interior traits that ethnohistorians suggest that the Wasco/Wishram

Minor, Aboriginal Settlement, 16. 
occupied a median position between the Northwest Coast cultures and those of the Plateau. ${ }^{32}$

Those bands living close to the mouth of the Columbia River, the Chinook proper, had traded sea otter pelts, hides, and sexual favors for copper and brass pots, buttons, knives, and cast-off clothing with Spanish, British, Russian, and American traders from circa 1765. Numerous sources indicated that the first direct white contact with the Natives of the Columbia River was when Captain Robert Gray crossed the bar and probed upriver. First mate John Boit wrote in his log on April 17, 1792, "[A] large canoe came along side full of the Natives. by their behavior, the Columbia was the first ship they ever saw." On April 22, 1792 he noted: "Sent the boat in shore often, but cou'd find no safe harbour. The Natives frequently came along side and brought otter furs and fish." A brisk business ensued during which native

\footnotetext{
32 Ames, "The Northwest Coast", 209-229; Ames, "Archaeology of the Longue Durée", 940, 942; Minor, "Aboriginal settlement", 6, 14; Spier and Sapir, Wishram Ethnography, 234 .
} 
foodstuffs and furs were exchanged for the whites' metal items. I believe, however, that Boit's supposition that the Columbia was the first ship to visit the river is implausible. It would not be intuitive for natives to fill their canoes with trade goods and approach an unknown vessel unless there had been some precedent. The Chinookans were talented and shrewd traders, offering the Europeans what they already knew would be valued as we see from Boit's passage. ${ }^{33}$

Down river Chinookans would rarely travel to the Dalles to trade. Only the elite, such as chiefs and important shamans, would paddle upriver to trade. The trade in local goods, conducted during the winter especially, was engaged in by both women and men. Ordinarily, Chinookans would trade closer to home for those items they desired, using their extensive trade networks to acquire the goods. The Chinookans were expert traders frequently exchanging items that originated from

33 Oregon Archaeological Society, Indian Trade Goods (Portland: Oregon Archaeological Society, 1993), 43; Herbert C. Taylor, Oregon Indians I: Anthropological 
as far as the coast to the plains, from Puget sound to northern California. The Dalles was a prime trading location along the river, with coastal and interior groups congregating there. The name for the Wishram village on the north bank of the Columbia was Nixlu'idix, which translates as "trading place." ${ }^{34}$

The Wishram were the middlemen along the Columbia, in company with the Wasco on the southern bank. The items most frequently traded along the Columbia River were slaves, salmon, dentalium (háikwa), skins, furs, oil, roots, pemmican, feathers, robes, clothing, and horses. The direction of the trade appears to have been items from the south and southwest exchanged for items originating in the north and northeast. ${ }^{35}$

While camped at the Dalles on November 1, 1805, William Clark noted in his journal that Chinookans paddling three canoes loaded with dried and pounded fish

Investigation of the Tillamook Indians (New York: Garland Publishing, Inc. 1974), 109.

${ }^{34}$ Hajda, "Regional Social Organization", 172; Ames, "The Northwest Coast", 223; Spier and Sapir, Wishram Ethnography, 224 .

35 Spier and Sapir, Wishram Ethnography, 225. 
were headed down river with the intent of trade for beads and copper. Clark wrote he could not discover whether the Chinookans were trading with whites or other Natives. Clark also observed that the beads they obtain in trade down river were then exchanged upriver for skins and robes. ${ }^{36}$

The Corps of Discovery found the Chinookans "avaricious and grasping," but conversely, commented that the natives were kind, hospitable, and friendly. They wrote that the Chinookans and others below the Cascades were "mild, inoffensive people but will pilfer if they have an opportunity". The problem of theft increased among those Indians who had had the most contact with whites and probably originated in the whites' ignorance of local custom. This intersection of two disparate cultures and the resultant reactions of each group will be examined more closely in the next chapter. ${ }^{37}$

\footnotetext{
${ }^{36}$ Moulton, Journals, vol. 5, 367.

37 Moulton, Journals, vol. 6, 165; Hajda, "Regional
}

Social Organization", 180. 
Prior to physical contact with whites, bacterial and viral contagions prevalent in EuroAmerican cultures were disseminated along the Columbia River most likely via the natives' trade networks. According to Boyd, the first EuroAmerican disease to infect the natives at the Dalles was smallpox. Introduced between 1775 and 1781, smallpox rapidly spread through the "virgin soil" population at the Dalles killing a large number of natives. ${ }^{38}$ Trading with whites allowed the close proximity required to spread bacterial, viral or parasitic contagions such as measles, malaria, smallpox, and whooping cough. Diseases such as fever and ague (which may have been malaria), measles, cholera, and smallpox devastated the native populations along the lower Columbia River in the last quarter of the 18th century. By 1836 the population stabilized; those having survived the epidemic returning to their seasonal rhythms only to be plagued by smallpox, followed by dysentery the next decade. Missionaries and explorers who followed in the wake of the epidemic witnessed only a remnant population. The fraction who survived consolidated 
their villages to ensure the distribution of labor in order to procure and preserve vital food resources. ${ }^{39}$ to the Reservation Era" (MA thesis, University of Oregon, 1979), 101; Silverstein, "Chinookans of the Lower Columbia", 535 . 
Lewis and Clark's Estimates of the Native Populations

\begin{tabular}{|l|l|l|l|}
\hline Multnomahs & $1805 / 1806$ & Wasco/Wishram & $1805 / 1806$ \\
\hline Nechacokee & $100 / 100$ & Eskellute & $600 / 1000$ \\
\hline Shoto & $160 / 460$ & Chilluckkittequaw & $1000 / 1400$ \\
\hline Multnomah & $200 / 800$ & SmockShop & /800 \\
\hline Clannahqueh & $130 / 130$ & & \\
\hline Nemalquinner & $100 / 200$ & & \\
\hline Cathlacommahtups & $70 / 170$ & & \\
\hline Cathlahnahquiah & $150 / 400$ & & \\
\hline Clackstar & $350 / 1200$ & & \\
\hline Claninnata & $100 / 200$ & & \\
\hline Cathlahcumups & $150 / 450$ & & \\
\hline Clannarminamon & $280 / 280$ & & \\
\hline & $300 / 900$ & & \\
\hline & $2090 / 5290$ & & \\
\hline & & & \\
\hline
\end{tabular}

Table 1

Lewis and Clark identified five separate villages of the Multnomahs as follows: on the inlet were the Cathlacomahtups and the Clahinnata, on Sauvie Island were the Cathlanaquiahs, the Cahtlacumups, and the 
Clanaminumums. Keep in mind, however, that the corps of Discovery inspected Sauvie Island from the banks of the Columbia which means they missed any other villages in the interior of the island. From the Cascades to the Dalles were the Chilucketiquaws (variously spelled Chilluckitiquaws, and Chillucketiqua), Smackshop, and Echeloots. ${ }^{40}$

40 Moulton, Journals, vol. 6, 490, 488 fn. 1, 474-486, passim. 
The Chinookans at Contact:

White Traders' Market Economy

This chapter will examine the intersection of two distinct cultural views of trade, the mechanisms by which items were traded in the native economy, and how the Multnomahs at Fort Vancouver and the Wasco/Wishram at the Dalles responded to the introduction of European manufactured goods and philosophies.

In the late eighteenth and early nineteenth centuries the Pacific Northwest coast was a venue for trading among the Natives, Spanish, British, American, and Russian explorers and traders. Metal items were most coveted by the Native Americans while the whites traded for furs for the European and Asian markets, and to replenish their foodstuffs. Such interaction between Natives and Europeans nurtured a florescence of cultural and material exchanges that continued through the mid-nineteenth 
century in the Pacific Northwest. European expansion into the realm of the Chinookans was driven by the desire of Europeans and Chinese for furs. ${ }^{41}$

In 1780 the United States Congress passed Indian Trade and Intercourse Acts to regulate the trade between whites and natives to protect the latter from unfair practices. Congress saw trade as a means of 'civilizing' the natives, inducing them to settle and adopt a sedentary lifestyle. To assist in accomplishing that goal, on June 20, 1803, President Thomas Jefferson instructed the Corps of Discovery, led by Captains Meriwether Lewis and William Clark, to ascertain "[t] he commerce which may be carried on with the people inhabiting the line you will pursue. . - the [locations to be determined] for mutual emporiums [of trade] . . . . "42

At contact, the Chinookans' economy was based on exchange of goods at a rate that seemed inelastic. Into

${ }^{41}$ Philip D. Curtin, Cross-cultural Trade in World History (Cambridge: Cambridge University Press, 1957), 207. 
this arena the Euro-Americans introduced capitalism. To give some historic background, capitalism emerged as a new economic system that helped propel the market economy. The three factors of production (land, labor and capital), are separated in a market economy. In premarket economies, land, labor, and capital are inextricably blended in the social structure. In the context of eighteenth century European economics, the market was the mechanism that produced prices. This type of market system was absent on the Pacific Northwest coast when maritime traders first encountered the Native peoples. One major difference between trade dominated by EuroAmericans and aboriginal trade was that aboriginal trade was not based upon a standard medium of exchange. When trading with other native groups, Chinookans traded foodstuffs, háikwa, and furs for prestige items such as obsidian blades, horses, and slaves. The price of an item might have been fixed or simply been the traditional price within the sphere of the Chinookans' trade network. Yet

${ }^{42}$ Jackson, Letters of the Lewis and Clark Expedition, 62. 
with the influx of Euro-American traders offering new technologies, materials, and ideas, the traditional prices of goods were challenged and altered by the Chinookans to reflect the adoption of these unique ideas. ${ }^{43}$

The Corps of Discovery repeatedly noted that the Natives along the Columbia were catching and drying fish in "great quantities". A basket of dried, pounded salmon was estimated to hold about 90-100 pounds of pulverized salmon. These seem to have been as standard size, perhaps due to the extensive trade in dried salmon. Fish being prepared for market was left in the baskets, covered with salmon skins, and 12 baskets stacked together. The stack was covered with rush mats and tied securely. Ecological differences from one region to another along the lower and middle Columbia River encouraged trade among the various indigenous peoples.

For the Euro-Americans, the two most important items in the Pacific Northwest fur trade were the sea otter and

${ }^{43}$ Karl Polanyi, Conrad M. Arensberg, Harry W. Pearson, eds., Trade and Market in the Early Empires 
beaver. Beaver was used to make felt hats which were popular in Europe. The push to satisfy the demand of fashion consumers in Europe practically eradicated the beaver population in North America as it had in Europe. Sea otter was used to trim the garments of high-ranking Chinese. The Hudson's Bay Company used a single stratagem by which they collected the furs. Having failed to entice the Natives to hunt or trap more intensively, the traders sent a party of trappers, called a brigade, to collect the furs by either actively trapping, or trading in the natives' villages. The goal was to deprive any rival trading company of furs, thus discouraging competition. ${ }^{44}$

When determining where to build a fort, the HBC searched for locations that would facilitate two-way shipment, and provide habitat for fur bearing animals. The native population brought furs and foodstuffs to trade for blankets, foods, and manufactured goods, and at the

(Glencoe: The Free Press, 1957), 358, 366.

44 Burt Barker, ed., Letters of Dr. John McLoughlin Written at Fort Vancouver, 1829-1832 (Portland: Binfords \& Mort, 1948), 63, 66, 195-6; F.G. Young, ed., The Correspondence and Journals of Captain Nathaniel $J$. Wyeth, 1831-6, (Eugene: University Press, 1899), 250. 
same time lay in their yearly supply of salmon. Fort Vancouver was the principal location along the Columbia River from which all supplies were furnished to other HBC factories. ${ }^{45}$

Thomas Jefferson Farnham traveled to the Columbia River from St. Louis, Missouri, and noted in his journal,

[The Hudson's Bay Company is] thus doing incalculable good to the territory, and rendering it more valuable for future settlers [by farming the land surrounding the fort.] At the same time, this exerts an influence in domesticating the Indians, not only by changing their habits, but food, and attaching them to a locality. ${ }^{46}$

Native men and women were involved in trade and barter at the forts and in their villages. At the Dalles, the Wasco and Wishram traded with visiting people from different areas and language groups. While many items

\footnotetext{
${ }^{45}$ Curtin, Cross-cultural Trade, 214.

46 Thomas Jefferson Farnham, Travels in the Great Western Prairies, the Anahuac and Rocky Mountain, and in the Oregon Territory in Reuben G. Thwaites, ed., Early Western Travels: 1748-1846, vol. 2, (Cleveland: The Arthur H. Clark Co, 1906), 96.
} 
exchanged hands by gambling, it was not the primary method of trade. ${ }^{47}$

The trading network of the Chinookans was woven from the thread of commercial relationships with distant peoples, and intermarriages. It was at the Dalles, at the cusp of spring and summer, that far-flung peoples gathered to trade, fish, race, find marriage partners, and gamble. As traders, the Wasco and Wishram held a superior position in the social hierarchy along the Columbia River. As middlemen of commerce, the Wasco and Wishram occupied a powerful position in which they controlled the movement of items being conveyed from one region to another. The vicinity of the Dalles was probably the most considerable trading establishment of the whole Northwest, marking the convergence of interior and coastal groups. The fishery at the Dalles was a powerful draw. Those groups who had marriage ties at the Dalles had hereditary rights to fish at family controlled fishing sites. Trading partners from the plateau and coast gathered there, trading food items for pounded salmon packed in baskets. Thomas Farnham 
wrote that, "[t]he Indians from many quarters flock to the Dalles and the Shutes in the spring, and autumn, and winter to purchase salmon. . ." The Wasco and Wishram, as the eastern-most Chinookans, were exposed to a variety of ideas from the Plains, Plateau, and Coastal peoples as a result of their position along the major trading routes and fisheries. ${ }^{48}$

Two methods of trade have been identified for the Chinookans. One is market exchange (or two-way exchange) which consisted of a reciprocal, balanced flow of goods and services between groups. The second is transferring (or one-way exchange) of goods. Two-way exchanges were more obvious and observable, and involved overt forces of supply and demand. One-way exchanges involved reciprocity that was not observably tied to a transaction; the driving

${ }^{48}$ Robert H. Ruby and John A. Brown, The Chinook Indians: Traders of the Lower Columbia River (Norman: University of Oklahoma Press, 1976), 21; Farnham, Travels, 359; Spier and Sapir, Wishram Ethnography, 159; James A. Teit, "The Salishan Tribes of the Western Plateau" in Forty-fifth Annual Report of the Bureau of Ethnology to the Secretary of the Smithsonian Institution 1927-28 (Washington: Government Printing Office, 1928), 147. 
forces are covert and may have been constrained by ceremony, kinship, formalized exchange rates, or closely matched exchange goods. Two intersecting native economies were present as well. A prestige economy in which prestige goods were exchanged for other prestige goods, and a subsistence economy in which food and clothing items were exchanged. A three-way paradigm of exchange may have been at work among the Chinookans, the patron-brokerclient model. In this manner an individual who aspired to become an elite member within the village hierarchy assumed the patron role by distributing items and services to potential followers with no clear condition or expectation of reciprocation. As white traders insinuated themselves in the local economy, they assumed the role of client, presenting goods that were unique and highly desirable. The broker role is one in which the value of goods and services are identified by the patron and passed along in toto to the client. The final link in the chain of trade is the client who received the goods and services and understood implicitly that a return was expected. An asymmetric relationship existed in that the patron 
ultimately controlled both the direction and value of the goods and services being passed. The intrusion of the Hudson's Bay Company and competing American fur trading companies in the Columbia River region thrust the Chinookans into a defensive position. At the outset of their introduction native-white relations were more an elaboration of native trading patterns than a paradigm of Euro-American customs. Had the traders understood the structure of native trade customs there would have been fewer thefts and misunderstandings between themselves and the native groups with whom they traded. Social distance between natives and whites also may have encouraged petty acts of insolence toward white traders and explorers. ${ }^{49}$

The Wasco and the Wishram, situated on opposite sides of the Columbia River at the Dalles have been identified by anthropologists and historians as prominent traders in

${ }^{49}$ Frederic L. Pryor, The Origins of the Economy: $A$ Comparative Study of Distribution in Primitive and Peasant Economies (San rancisco: Academic Press, 1988), 27; Hajda, "Regional Social Organization", 28-31; Kirk Garrison, "Lewis and Clark at Fort Clatsop: A Winter of 
the Dalles region prior to white contact in the early 19th century. Trade goods, items of European and American manufacture, grew in prevalence after 1840 along the Pacific Northwest coast. Many of these items filtered inland via the extensive trade network built and nurtured by the Chinookans. ${ }^{50}$

The importance of their location cannot be over emphasized. The series of rapids leading from the Dalles to the mouth of the Columbia were difficult to run in a canoe. The natives had advised the Corps of Discovery to portage their craft around the obstructions. As a natural barrier, the short and Long Narrows constituted a break in transit. Break in transit is a term that defines a location where customary transportation of goods is halted for an alternative mode. This natural bottleneck proved to be an economic benefit to the local population. The Wishram were famous for a trade market that encompassed a vast territory and numerous peoples of distinct languages and cultures. Spier and Sapir note in their ethnograph

Environmental Discomfort and Cultural Misunderstandings" (Masters Thesis, Portland State University, 1997), 48. 
that the Wasco and Wishram were proud of their reputation as traders, and named their principal settlement Nixlu'idix (now Spedis, Washington). The vicinity of the Dalles was probably the most considerable trading establishment of the whole Northwest. The Wasco and Wishram traded in their own villages, jealously protecting their position as middlemen. Generally, products of the lower Columbia, the Coast, and the southern or Oregon country, were exchanged for products of the interior east and north. Furs sold by the Dalles peoples to the Hudson's Bay Company were all procured from other tribes. In later days they had few for sale, as the native trappers traded directly with trading establishments or their representatives. The Wasco/Wishram generally were more or less hostile to the white traders. They interfered with the passage of North West Company and Pacific Fur Company personnel and other white traders along the Columbia River as early as 1811. The Wasco and Wishram resented the whites directly trading with 
neighboring villagers, considering that they should by rights act as middlemen. ${ }^{51}$

An exception was made in 1829 for an American trader named Bache. Bache had married a woman from one of the Dalles tribes and, undoubtedly, both the American and the Chinookans utilized traditional native exchange customs to draw each other closer. Euro-American traders who went abroad to trade without wives from home often married native women. The Chinookans were eager to bring the white traders into their fold, marrying their women to the whites to create a bond of kinship through which they cultivated a secure trading partnership, and helped speed the process of culture change. Bache's brother-in-law was a man of wealth and a chief. By extending his influence via kinship ties to his wife's family Bache successfully traded with the Dalles people until his untimely death by drowning a year later. John McLoughlin recognized the threat engendered in Bach's presence at the Dalles, and sent one of his clerks to open a trading post to compete

${ }^{51}$ Spier and Sapir, Wishram Ethnography, 224-5; Ross, Adventures of the First Settlers, 129, 195, 240; Cox, The 
with Bache. It is reasonable to assume that the Chinookans tolerated the $\mathrm{HBC}$ fort on the north side of the river across from Bache's establishment hoping to benefit from the competition. I found it interesting that soon after Bach's death, the HBC post at the Dalles closed, and the clerk and his staff recalled to Fort Vancouver. Certainly McLoughlin recognized the value of an establishment situated at the heart of the trading sphere. Why McLoughlin did not maintain his presence at the Dalles may be tied to the difficulty encountered in the logistics of supplying and staffing that particular post. McLoughlin was concerned that both Fort Vancouver and Fort Bach would be at risk of attack as a result of dividing his staff between the two posts. ${ }^{52}$

Alexander Ross of John Jacob Astor's Pacific Fur Company found himself among the Wasco and Wishram at the Dalles in August of 1811. He commented that the regular

Columbia River, 76-77, 123 .

52 Burt Barker, ed., Letters of Dr. John McLoughlin Written at Fort Vancouver, 1829-1832 (Portland: Binfords \& 
inhabitants of the settlement did not exceed 100 persons but the population swelled to over 3,000 during the salmon season which ran from April through October. In Ross's opinion the visitors were not necessarily present to fish, but to gamble and trade. Ross claimed, "The long narrows [the Dalles], . . is the great emporium or mart of the Columbia, and the general theatre of gambling and roguery." Lewis and Clark described the activity they observed among the natives as trade when they passed through the Long Narrows (their appellation for the Dalles) in $1805 .{ }^{53}$

White Impact on the Chinookans' Culture and Economies The Pacific Northwest fur trade involved a meeting between market-oriented Europeans and native Americans who had been isolated for many centuries. As intermediaries in the economy of the Pacific Northwest the Chinookans

Mort, 1948), 57, 60; Wyeth, Correspondence and Journals, 175 .

53 Alexander Ross, Adventures of the First settlers on the Oregon or Columbia River, 1810-1813 (Lincoln: University of Nebraska Press, 1986), 129; Moulton, Journals, vol. 5, 367 . 
were exposed to Euro-American technologies, ideas, and markets. Chinookan culture was dynamic; the people adopted ideas and technologies they found useful and adapted them to their own use. ${ }^{54}$

Spanish and Russian maritime traders had bartered with coastal peoples as early as the 1740 s when pelagic furs such as sea otter (Enhydra lutris) and harbor seal (Phoca vitulina) were exchanged for beads, buttons, clothing, copper and brass cookware, firearms, and sheets of copper. By 1798 the price of furs on the London market dropped which was relieved by opening trade in China. James Hallowell, a partner of the North West Company reported ". . . that China would absorb considerable quantities [of furs] at good prices, could relieve the glut on the London market and raise [fur] prices there." In the quest for trade with China, American and British traders joined the onslaught of the fur trade shortly afterward. With the coming of the white traders, the natives simply intensified traditional occupations such as

${ }^{54}$ Pettigrew, "Prehistory of the Lower Columbia and Willamette Valley", 523. 
hunting and trapping instead of initiating an untried activity. ${ }^{55}$

The Chinookans' economies were far more selfsubsistent, and their technology and trade systems less developed than Euro-Americans' technology and trade systems. Generally, trade ran a broad gamut of possible relationships, from mutual raiding and plain robbery, through a variety of ritual ceremonial exchanges with important social and political functions. Friendships with distant natives were strengthened through ritual exchange of valuables. ${ }^{56}$

The introduction of firearms to the Chinookans' material culture added an interesting twist to their trading practices with other native peoples. Chinookans who had contact with white traders had a distinct advantage over those native groups without access to this

55 E.E. Rich, ed., The History of the Hudson's Bay Company, 1670-1870, vol. 2: 1763-1870 (London: The Hudson's Bay Record Society, 1959), 564; Wilcomb E. Washburn, ed., Handbook of North American Indians, History of Indian-White Relations, vol. 4 (Washington: Smithsonian Institution, 1988) 356, 375. 
new technology. In the late 18th century chief concomly told Captain Charles Bishop how the Chinooks traded for furs and hides,

[we] go up the River Chinnook [sic] two or three hundred miles and come to strange villages, where they land and offer trade with some trifling Pieces of Copper or Iron. the strangers naturally demand more. the chief then gives the Signal and they all discharge their Pieces laden with Powder, into the Air. These People never having heard or seen such a strange Phenomenon throw off their skins and Leather war Dresses and fly into the woods, while the others Pick them up, and leave on the spott [sic] the articles first offered. They then Proceed to Other Places in like manner. ${ }^{57}$

The balance of power between the traders and the Chinookans was necessarily asymmetrical. The traders were specialists in a single kind of economic enterprise, whereas the Chinookan society was a whole society, with many occupations (such as fishing, mat making, basket weaving, and woodworking), and class stratification: elite, commoners, and slaves. To speculate, the HBC may

56 Curtin, Cross-cultural Trade 225, 229; Sapir, Wishram Texts, 104; Sapir and Spier Wishram Ethnography, 234-5. 
have appeared to the Chinookans as a similar culture, the factor and traders part of the elite, and the trappers corresponding to commoners. In this paradigm the native chiefs would manage the trade between his perceived counterpart in the $\mathrm{HBC}$ hierarchy. ${ }^{58}$

Competition among the various trading concerns proved to be beneficial to the Chinookans. Chief Factor John Mcloughlin reported to Hudson's Bay Company Governor George Simpson that the American ship captain John Dominis, employed by Boston merchant Josiah Marshall, commenced trade immediately on arriving at the columbia River. Dominis offered much lower prices than the Hudson's Bay Company: 6 skins for a gun, and 2 skins for 2 $1 / 2$ point Blankets, whereas the Company's prices were 18 skins for a gun, and 5 for a blanket. The threat of competition also prompted McLoughlin to send a delegation

\footnotetext{
57 Michael Roe, ed., Journal and Letters of Capt. Charles Bishop on the Northwest Coast of America, 17941799 (Cambridge: Hakluyt Society, 1967), 118-119. 58 Curtin, Cross-cultural Trade, 5.
} 
to the Dalles in 1829 in response to Bache's trade emporium (see page 46.$)^{59}$

Not surprisingly, the location of the forts also effected the locus of Chinookan power. Following the merger of the North West Company and the Hudson's Bay Company in 1821, the resultant move from Fort George to Fort Vancouver transferred control of white trade from Concomly's hands at the coast to Casino's hands farther up river in 1825. Casino's status skyrocketed among the Columbia River natives as he gained control of the flow of goods moving between the Chinookans and the traders. The rivalry between Concomly and Casino escalated as Concomly spread rumors among the upriver natives that the whites were "very bad people" in the hopes of deterring the Chinookans from visiting Fort Vancouver. Concomly's scheme was to continue funneling all trade through himself, skimming a nice profit in the process. ${ }^{60}$

\footnotetext{
77.

59 Rich, The Letters of John McLoughlin, First Series, 60 Ibid, 4-5; Silverstein, "Chinookans of the Lower Columbia", 535 .
} 
Technology Changes

In the late 18th century white maritime traders, beginning with Captain Robert Gray in 1792, ventured past the bar at the mouth of the Columbia to explore and trade with the people living along the riverbanks. Although the mariners did not penetrate beyond 120 miles upstream at that time, their manufactured items preceded them upriver. By means of the extensive trading network these goods, which were both novel and utilitarian, trickled into the interior. When Lewis and Clark encountered the Chinookans in the autumn of 1805 they observed items of European and American manufacture already in their possession. ${ }^{61}$

Metal kettles and pots were prized as cookware in addition to the woven baskets used for cooking. When their original usefulness was over the pots were melted down for projectile points, woodworking tools, and fishing hooks. These metal points augmented the traditional 
projectile points made of stone, bone and antler. Guns were added to the equation which took the place of lances, bows and arrows. We have already seen the impact of firearms in cultural relations.

Glass beads, that standard of trade goods, augmented porcupine quill, animal bones and teeth, dentalia (háikwa) shells, feathers, and stone beads as a form of adornment to the Chinookans' clothing. Seed beads (so-called because of their small size) were sold in hanks of about ten strands each. The natives of the columbia especially desired blue and white seed beads.

Metal axes (made of iron or tempered steel) were added to stone axes for wood working. Occasionally, metal objects of Russian, Spanish or Japanese origin were traded to the natives along the Columbia. These highly prized materials were also salvaged from shipwrecked vessels that washed ashore. An occasional helpless Japanese cargo ship drifted across the Pacific on the Kuroshio, or Japanese Current. Once washed ashore the ships were stripped of anything useful to the natives. Surviving sailors were enslaved if they were not killed on the spot. Once in the 
hands of the natives, the metal goods were reworked to form more utilitarian items such as adzes, chisels, knives, and axes. Metal adzes and chisels were highly prized among the upper class of the Chinookans as wood working was an occupation reserved for the elite. ${ }^{62}$

Wool (especially duffels, a heavy fabric of Dutch manufacture) and cotton clothing, and fabric were prized items. Notwithstanding the novelty of the clothing, the functionality and light-weight warmth that wool clothing provided in the damp climate of the Pacific Northwest proved to be valuable to the Chinookans. These items augmented the animal skin, and cedar bark clothing produced by the women.

\footnotetext{
Katherine Plummer, The Shogun's Reluctant

Ambassadors: Japanese Sea Drifters in the North Pacific (Portland: OHS Press, 1991), 236; Hajda, "Regional Social Organization", 146; Mary Gormly, "Early Culture Contact on The Northwest Coast, 1774-1795: Analysis of Spanish Source Material" in Northwest Anthropological Research Notes, Spring 1977 (11): passim; Warren Cook, Flood Tide of Empire, (New Haven: Yale University Press, 1973), 33-34; Grant Keddie, "The Question of Asiatic Objects on the North Pacific Coast of America: Historic or Prehistoric?" in Contributions to Human History, (Royal British Columbia Museum, March 19, 1990 (3): 2 ; Ramsey, Coyote Was Going There, 174-5.
} 
All of the above mentioned items were the result of large scale industrial manufacturing which the Chinookans were incapable of at that time. The only metal available was native copper originating in Alaska, which was used exclusively for ceremonial purposes or personal adornment, metal items acquired through trading, or metal recovered from shipwrecks. European metal goods provided an excellent alternative for those items of native manufacture.

The earliest trade with whites was little more than a by-product of the European presence on the coast. Exchanges of Chinookan foodstuffs and furs for European clothing and metal items initiated the interest in trade on a larger scale. When the fur trade began, it had a profound impact on the Native societies, most obviously because it supplied the new tools and weapons which led to further social and political changes, one of the most immediate of which was manifested in the economic and military rivalries within native society. One new pattern that appeared almost at once, and recurred frequently, was 
that any native group that first made contact with the Europeans might then try to monopolize trade by force. This was certainly the experience of Alexander Ross, one of the traders at Fort Astoria, who reported that "the distant tribes were forming some dark design of cutting us off, and reports countenancing this belief were daily brought us by Comecomly and his people." Chief Concomly, always with an eye for his own well-being, claimed that the "hostile tribes were a very bad people, and illdisposed towards the whites. . . " "The Astorians believed Concomly because "Comecomly and his people were the only Indians who had regularly traded with us. . . " Later Ross discovered that Concomly had

fomented and nourished the misunderstanding between us and the distant tribes. . . . By this stratagem [sic], they kept them from coming near us--thereby monopolizing all the trade themselves, by buying up all the furs, and selling them again to us at double their first cost. ${ }^{63}$

${ }^{63}$ Curtin, Cross-cultural Trade, 219; Ross, Adventures, 94-95. 
Although this example focuses on the Chinookans at the mouth of the Columbia River a similar situation occurred with Casino at Fort Vancouver.

I believe the work-ethic doctrine among missionaries and white traders hindered the establishment of more friendly and meaningful relationships between the natives and Euro-Americans. The Wasco/Wishram were predictable in their season rounds as food sources became available. They fished and preserved most of their catch during the spring and summer, collected roots, berries, and nuts during the fall, and produced baskets, mats, clothes, and tools during the winter months. Compare this to the missionaries who planted their fields in the spring, cultivated the rows during the summer, and harvested the crops in the fall, repaired equipment during the winter. While this may be a simplistic comparison, it refutes the term "indolent" the missionaries repeatedly used to describe the Wasco/Wishram. As with all initial culture intersections, there were some misunderstandings. People of different cultures often have different attitudes 
toward material goods. This was certainly true of the Euro-American fur traders and the Chinookans. The natives saw the whites as being rich beyond measure, yet incredibly miserly. The Chinookans could not comprehend why the whites, who had such obvious wealth, were not more liberal in their gifts. White traders were ignorant of the traditional native practices followed to ensure a closely knit trading partnership. For many native groups, and the Chinookans specifically, mutual gift giving was important in establishing friendly relations, both between and within groups. The missionaries noted numerous times the begging of the Chinookans, and were quite annoyed by this behavior. Jason Lee noted in 1843 that Peu-Peu-MoxMox, leader of the Walla Wallas, inquired if Dr. Elijah White intended to present gifts to the villagers in Dr. White's capacity as US government representative. Lee retorted that ". . .to be always looking for gifts was a sure sign of laziness, for the industrious would rather labor and earn a thing than to beg it." Alvan Waller was exasperated by the Wasco and Wishram's invented errands which deteriorated to "begging" for some trivial item. He 
wrote in his journal on May 24, 1845, that "near twenty Indians in a body came to my house to-day, with seemingly little or no errand. . . soon commenced begging. . . ." Waller failed to recognize that the Chinookans were attempting to cement the bonds of friendship between themselves and the missionaries with a ritual gift exchange. ${ }^{64}$

Wealth carried prestige, but only when the wealth was redistributed in the form of gifts. Native Americans occasionally perceived surplus goods to be theirs for the taking, which led to egregious misunderstandings among the Euro-American traders. This did not mean that Native Americans disdained the possession of material goods or personal possessions. Trade was, indeed, a prime way to acquire the goods that conferred prestige, built influence, and cemented bonds between distant peoples. On the other hand, the Chinookans were ignorant of the

${ }^{64}$ Curtin, Cross-cultural Trade, 226; Ross, Adventures, 124-5; Spier and Sapir, Wishram Ethnography, 228; Cornelius J. Brosnan, Jason Lee, Prophet of the New Oregon (New York: The MacMillan Company, 1932), 202; waller MSS, folder 11. 
European concepts of market, supply, demand, money and price as the Europeans understood them. ${ }^{65}$

The Wasco and Wishram peoples in particular were generally hostile to white traders. Not only did the whites ignore native trade protocols, they circumvented the carefully maintained distribution system, threatening to usurp the Wasco-Wishram's position as traders at the Dalles. The native peoples presumed they had the exclusive right to act as middlemen in the trading network and resented the direct trade of the whites which could seriously affect their profits. ${ }^{66}$

Prior to and concurrent with Euro-American presence, the circulating medium among the Chinookans was the háikwa (dentalium) shell which is thin, light and durable. However, with the arrival of Euro-American traders, beaver pelts were also added as currency. "Made Beaver," as the pelts were termed by the Hudson's Bay Company, were of two types: coat beaver, pelts worn by Indians for a winter or

\footnotetext{
${ }^{65}$ Ross, Adventures, 131; Curtin, Cross-cultural

Trade, 127; Curtin, Cross-cultural Trade, 226.

66 Spier and Sapir, Wishram Ethnography, 225; Farnham, Narrative, 337 .
} 
more prior to trading; and parchment beaver, the skins taken and processed exclusively for exchange purposes. John McLoughlin used Made Beaver in his transactions with both white trappers and native traders through the years he was Chief Factor at Fort Vancouver. The Made Beaver exchange rates were changed very infrequently. The rate of value for Made Beaver was set annually by the Governor and Board of the HBC. I find this fact interesting considering the principals of capitalism and market that were in force among the white traders. That the exchange rate was not responsive to the local economy but regulated by distant factors appears to be an anomaly of economic theory and the market system at work along the lower Columbia River. ${ }^{67}$

In fact, in the short-term these rates appeared to be inelastic. Given the fluctuations of the commodity and trade goods markets in Europe, this price rigidity seems remarkable. This may have been the result of the

\footnotetext{
67 Rich, Letters of Dr. John McLoughlin, 23, 184, 197, 199; E. E. Rich, "Trade Habits and Economic Motivation Among the Indians of North America" in Canadian Journal of Economics and Political Science, vol. 26(1):35-53, 49.
} 
unwillingness of the Chinookans to respond to market forces because the natives operated in a context in which sociopolitical considerations, rather than impersonal supply and demand forces, played a paramount role in establishing prices. I believe it may also have been a result of the marketplace: without consistent competition the $H B C$ had no pressing need to adjust their prices downward to entice the Chinookans to remain loyal. The few ships that ventured past the bar and upriver did not present a sufficient threat to the traders at Fort Vancouver. Although McLoughlin was perturbed by the presence of two American brigs in the vicinity of Fort Vancouver in 1830, he took measures to secure all the furs the Chinookans had collected before the skins could fall into the hands of the Americans. ${ }^{68}$

The fur trade integrated European goods and traders into native gift relations and kinship networks just as History of Indian-White Relations (Washington: Smithsonian Institution, 1988), 340; Rich, Letters of Dr. John McLoughlin, 1, 92-93, 145, 221 . 
much as it linked native economies to merchant capitalism. Although markets existed in native America they were not price driven as were the markets in Europe and America. The exchange rate for items in the native economy was inelastic, based on custom and tradition, not supply and demand. 
The Introduction of European Diseases:

The "Columbian Exchange"

"The Indians are rapidly decreasing in all parts of the country; the causes are supposed to be their rude treatment of diseases. . . ."

Thomas J. Farnham, 1839.

In the latter part of the 18th century the introduction of diseases by Euro-American maritime traders and explorers to the indigenous peoples of the Pacific Northwest Coast was the final phase of a larger global process historians labeled the "Columbian Exchange." This term suggests the spread or exchange of ideas and other aspects of European culture between newly explored or colonized nations and themselves. As Euro-American traders and explorers penetrated into the interior along 
the Columbia River, they brought with them domestic plants and animals (sheep, chickens, swine), food preferences and biases, ideas, and most devastating of all, unknown diseases. Some of the introduced plants, animals and ideas were incorporated in the Chinookans' culture willingly, further enriching the Chinookans' culture. ${ }^{70}$

Infectious diseases indigenous to North America included dysentery, viral pneumonia, non-venereal syphilis, pinta (a contagious skin disease), leishmanisasis (a parasitic infection), trypanosomiasis (a parasitic infection of the blood that causes sleeping sickness), ricketts, tuberculosis, and trachoma (contagious form of conjunctivitis) ${ }^{71}$

Numerous diseases were introduced by Euro-American traders and explorers to the Native population on the lower Columbia River. But the two that had the most harmful effect upon the largest percentage of the

\footnotetext{
70 Crosby, The Columbian Exchange, 10. Boyd, The Introduction of Infectious Diseases, 39.

71 Boyd, Introduction of Infectious Diseases, 39.
} 
population were smallpox, and malaria (also called fever and ague.) These two are termed "crowd diseases", requiring a dense population of susceptible individuals to spread. Smallpox is spread through droplet contamination, that is, an infected person spreads the contagion via sneezing or coughing. Malaria requires a three-part mechanism: dense population, mosquito vector (Anopheles malculipennis), and parasite (Plasmodium falciparum). Malaria is caused by a parasite which spends it life cycle in two hosts of different species. The primary host is an Anaopheline mosquito, and the secondary host is a warmblooded animal, necessary to the life-cycle of the malarial parasite. ${ }^{72}$

Robert Boyd, in his doctoral dissertation, speculated that upwards of 33 percent of the Chinookans died as a result of the smallpox epidemic of the mid-1770s, and a second epidemic in 1801. In 1829, there was an epidemic of ague fever, probably malaria, which in a single summer swept away greater than 80 percent of the remaining native

72 Boyd, Introduction of Infectious Diseases, 10 ; Boyd, People of the Dalles, 142 . 
population. Whole villages succumbed, and others were so depopulated that several were consolidated or were submerged by other groups. Chinookan men typically possessed rights to specific resources at very specific locations and thus resisted leaving their home village. ${ }^{73}$

The human devastation that resulted from these illnesses did more to clear the Oregon territory for white settlement than any other force that was brought to bear. The indigenous peoples of the Columbia River were populations which had never experienced these diseases.

Their traditional responses proved to be ineffectual in all cases, and fatal in most instances. Yet these alien diseases did more than depopulation the region, they also affected the power structures within the local village and the inter-village kinship ties by reducing the number of elites. ${ }^{74}$

First reports show a growing population prior to general white presence. To put the population loss in ${ }^{73}$ Boyd, The Introduction of Infectious Diseases, 95,
$304,314,317$; Spier and Sapir, Wishram Ethnography, 163. 
context, in October 1792, Lt. William R. Broughton, commander of the Chatham, observed 350 Chinookan men in canoes which he conjectured represented an estimated population of 1,400 around Sauvie Island and in the surrounding Multnomah villages. Thirteen years later, in November 1805 Lewis and Clark tallied 650 Chinookans. On their return up the Columbia in April, the Corps of Discovery noted 1,830 villagers in the same location. The disparity in Lewis and Clark's numbers from one year to the next represents the seasonal movements of the Chinookans from their permanent villages to seasonal campsites. The April census may also include peoples from outside the local villages who had come to collect food items. By 1835 the smallpox and malaria epidemics completely wiped out the Multnomahs living on sauvie Island. The diseases had swept through the native population so quickly there were none to bury the deceased. ${ }^{75}$

${ }^{74}$ Crosby, The Columbian Exchange, 54. 
Between the Cascades and the Dalles in October 1805, Lewis and Clark estimated the total number of Chinookans at more than 5,100 , in the wake of two smallpox epidemics in circa 1775 and 1801 from which the native population suffered a tremendous loss. Presuming 90\% loss from diseases, pre-contact population figures then could be estimated to be 45,900 in the region between the Cascades and the Dalles. In June 1825, John work claimed there were more than 700 Chinookans between the Cascades and the Dalles, although he noted there were "a good many Indians" along the river, failing to quantify this estimate. Like Lewis and clark before him, work neglected to indicate whether the natives he observed were permanent residents, or visitors who were preserving winter provisions. Alvan F. Waller, Methodist missionary visiting the Dalles in 1845, was dismayed by the return of dysentery "which proved so mortal last Autumn." By 1846 the estimated number of Chinookan survivors between the Cascades and the Dalles was 800. Paul Kane noted in 1846-47 that "[t] he

\footnotetext{
75 Boyd, Introduction of Infectious Diseases, 271-272; Wyeth, Correspondence, 149.
} 
Cascade Indians dwell upon the banks of the Columbia, about thirty miles lower down than the Fall Indians, and though formerly very numerous, are now almost extinct." The difficulty with this last conclusion is that Kane fails to mention the time of year in which he was making his observations. Alternatively, Kane may have been making a general statement to allude to the general loss in numbers the natives suffered. ${ }^{76}$

Native Beliefs in the Origins of Disease

Prior to contact the Chinookans believed the origin of disease was a result of an invasion of the body by an evil spirit. The Chinookans professed belief in a general good and a bad spirit. At the Dalles these were called skep and tah, respectively. In the Fort Vancouver

\footnotetext{
${ }^{76}$ Waller MSS, fol. 3; Moulton, Journals, vol. 6, 483; Mooney, The Aboriginal Population of America North of Mexico (Smithsonian Miscellaneous Collections, 80, 1927, 7), 13; John Work, "Journal of John Work", T.C. Elliott, ed., in The Washington Historical Quarterly, vol. 5, no. 2, (April 1914), 85-86, passim; Hodge, Handbook of American Indians North of Mexico, 274; Paul Kane, The Columbia Wanderer, 1846-47: sketches and paintings of the Indian and his lecture, Thomas Vaughan, ed., (Portland: OHS Press, 1971), 13.
} 
vicinity, they were the econe or good spirit, and ecutoch the bad spirit. The etaminuas, or shamans, were empowered to communicate with the econe. The keelalles, or doctors, administered medicine and cured diseases. Alvan Waller, visiting the mission at the falls of the Willamette, on February 1, 1841, noted in his journal that "[t]he Superstitious heathens suppose [the shamans] have the power to kill or cure the sick or kill the healthy by making them sick." While trading at the Dalles, Farnham had an opportunity to examine the Wasco/Wishram's ideas about disease. He described it as

[a] very curious philosophy. . . [in which] they believe human existence to be indestructible by the laws of nature; and never diseased, unless made so by the Medicine men or conjurers, who are believed to enter into the [body] in an unseen manner, and pull at the [vital organs]. ${ }^{77}$

Among the Wasco/Wishram were two designations of shaman, those who could cure (masculine, Idiaxilalit; feminine Itgaxi'lalit), and those who could cast spells

\footnotetext{
77 Henry K.W. Perkins, "Journal" in Robert Boyd, ed., People of The Dalles: The Indians of Wascopam Mission (Lincoln: University of Nebraska Press, 1996), 282; Ross.
} 
(masculine, Idiage'wam; feminine, Itgage'wam), or cause an evil spirit to invade a person. In the case of the latter shamans, the beliefs of the Chinookans resulted in numerous feuds. Survivors of the deceased who suspected that another person had paid a shaman to 'infect' their loved one would take matters into their own hands by avenging the death. The blame lay entirely on the accused, never on the shaman who merely acted as an agent. However, if the shaman was suspected of having his own motives for killing, his life was forfeited. Waller wrote that the shaman's life was at stake if the patient died, regardless of who was suspected of 'infecting' the victim. Waller is the only source to make this assertion. All other sources that I examined indicate the shaman's life was in danger only if he was suspected of having caused the patient's death through collusion with the evil spirits. ${ }^{78}$

Adventures, 110; Swan, The Northwest Coast, 182-183; Waller MSS, fol. 11; Farnham, Travels, vol. 1, 365. 78 Spier and Sapir, Wishram Ethnography, 215,245, 247; Waller MSS, fol. 3; Cox, The Columbia River, 178-9; Franchère, Narrative, 333. 
For example, Chief Casino, headman of the Multnomahs, suffered the loss of his son of an undetermined illness. Casino charged one of his wives with conjuring the child's death and attempted to kill his wife, but she escaped into the woods behind the village. Another instance was noted by the Reverend Gustavus Hines. In this incident a female doctor near the Dalles was unable to cure the only son of a man in the nearby village. Believing that the Itgaxi'lalit had purposely killed the child, the bereaved father barged into a church service conducted by Perkins and killed the woman as she sat in the congregation. ${ }^{79}$

Traditional Native Medical Intervention

In Wasco tradition, at the start of the medical treatment a shaman would take five puffs on his pipe, and dance to awaken his spirit to help with the patient's cure. Shamans sang and danced while helpers kept time with drumming. In the general Chinookan medical tradition, gathering of family members during curing 
sessions probably provided psychological benefit to the patient. Children who had yet to acquire a spirit guide were excluded from the ceremony on the premise that they had no protection from the invading spirit. For precontact illnesses this practice would have had little impact on the spread of diseases. However, with "crowd diseases" such as smallpox, the close proximity fostered by this tradition provided an excellent medium for spreading diseases to others. ${ }^{80}$

The gathering of participants and on-lookers may also have served as a declaration to the village of the shaman's powers should he or she prove to successful in producing a cure. If a powerful spirit was beyond the capabilities of the shaman, another was invited to assist. If the patient died the shaman would return the fee collected prior to agreeing to cure the victim. Otherwise, the shaman's life could be in jeopardy should the bereaved determine the shaman had an role in slaying the patient. ${ }^{81}$

\footnotetext{
${ }^{80}$ Boyd, Introduction of Infectious Diseases, 60-61; Ross, Adventures, 110.

81 Spier and Sapir, Wishram Ethnography, 245-246.
} 
The Chinookans' traditional medical response included sweating in the sweat lodge, then immersing the patient in a nearby stream, as well as herbal concoctions to be drunk as teas. Sweating and immersion was followed by wrapping the patient in a robe. The shaman would then rub, press, suck, and pull on the patient. Eyewitnesses to these therapeutic sessions commented on the force exerted by the shaman while manipulating the patient. Ross Cox reported that the procedure entails the shaman pressing his fists "with all his force" on the patient's abdomen. George Gibbs, who observed the Chinookans in the 1840s and 1850s, noted that "[t]he practice of medicine, . . consists of incantations - . . Besides these mummeries, however, they used certain plants as medicines, among which are both emetics and cathartics." 82

Febrile diseases such as malaria, smallpox and measles treated with sweat baths resulted in massive

\footnotetext{
${ }^{82}$ George Gibbs, Indian Tribes of Washington Territory (Executive Document No. 91, H. of Rep., 33rd Cong., 2nd Session Reports of Exploration and Surveys, to Ascertain the Most Practical and Economical Routes for a Railroad from the Mississippi River to the Pacific Ocean. . .1845; reprinted, Fairfield, WA: Ye Galleon Press, 1967), 11.
} 
numbers of deaths. Cox related this reaction in his journal as follows: "The unfortunate Indians, when in the height of the fever, would plunge into a river, which generally caused instant death . . . ." As a result of the disease and its treatment, "[w]hole villages were depopulated. . . . . " 83

The most dreaded disease to strike the Chinookans was Variola major or smallpox. First introduced from maritime traders in the mid-1770s, it spread with alarming swiftness through the riverfront villages, killing a majority of the inhabitants. From infection to recovery or death took approximately one month. The Chinookans had no resistance to this newly introduced disease. Those who survived the epidemic were marked for life with both immunity and terrible scarring. Traveling along the Columbia in 1814, Ross Cox noted that 30 years earlier, smallpox had swept through the region, "the vestiges of

\footnotetext{
3 Virgil Vogel, American Indian Medicine, (Norman: University of Oklahoma Press, 1970), 256-7; Farnham, Travels, vol. 1, 365; Franchère, Narrative, 333; Spier and
} 
which were still visible on the countenances of the elderly men and women." A generation later in 1801, smallpox again struck the natives of the Columbia, attacking new susceptibles born since the first epidemic. This smallpox attack is surmised to have killed over 30 percent of the remaining Chinookans, reducing the original population to about one half by the time of Lewis and Clark's arrival in 1805. Keep in mind that for every visitation of smallpox upon the Chinookans, it would affect only those who had not encountered it previously, thus a much smaller population of susceptibles. ${ }^{84}$

Many natives at the mouth of the Columbia and at Fort Vancouver, frightened by the specter of large numbers of their family members and neighbors succumbing to this disease, may have fled to distant relatives' villages. This action spread the disease to other populations east along the Columbia and south along the willamette. By this mechanism the natives at the Dalles were infected

Sapir, Wishram Ethnography, 269; Cox, The Columbia River, 169, 179. 
with smallpox in the late $18^{\text {th }}$ century. Lewis and Clark noted the presence of smallpox scarred "old men and women" at the Dalles in October of 1805 .

Although there are no population estimates for the Dalles region prior to the 19th century, it can be assumed that the percentage of Chinookans who succumbed to smallpox was greater than the 30 percent for 'virgin-soil' epidemics. To compare, Lewis and Clark's 1805-06 population estimate of 5,100 (see above) between the Cascades and the Dalles indicates how severely the natives were affected; by 1841 , only 355 remained at the Dalles and the Cascades. ${ }^{85}$

Giving but a brief respite to the Chinookans, the next epidemic to wreak havoc was malaria, or as it was ${ }^{84}$ Boyd, Introduction of Infectious Diseases, 18, 7172, 95, 108; Cox, The Columbia River, 169; Hunn, NCh'iWana, 27; Moulton, Journals, 285.

85 Boyd, Introduction of Infectious Diseases, 44, 95;

Farnham, Narrative, 99. Farnham states that the difficulty in obtaining an accurate count is due to the Chinookans' seasonal rounds. These figures are from Charles Wilkes' report, Synopsis of the Cruise of the United States Exploring Expedition during the years 1838, '39, '40, '41, and '42, published in Washington, D.C. 
known historically, fever and ague, also called intermittent fever. Ague was violent shaking due to chills, alternating with the fever of malaria. In 1830 the malaria epidemic was most disastrous below the Cascades. This may have been due to a combination of two factors: the first is the closer association the Chinookans had with white traders and emigrants. The second factor is the close proximity to the environmental conditions required by the $A$. malculipennis mosquito, the malaria vector. A. malculipennis prefers clean, slow moving or stagnant water with plenty of sun in which to support its nymphs. These specific conditions were most common around Fort Vancouver in the summer of 1830 . Plowing the HBC's 3,000 acres disturbed the surrounding basin, and may have created pools of standing water in which the mosquitoes could breed. During the late summer, the Chinookans camped along the Columbia slough to collect wapato which grew in abundance on Sauvie Island. The native Americans provided a moveable feast for the mosquitoes. Boyd speculates that an emigrant brought the malaria parasite to the oregon country. Chief Factor John 
McLoughlin wrote on October 11, 1830, that "[t]he Intermittent fever. . . has appeared at this place and carried off three fourths of the Indian population in our vicinity. . . ." Wyeth, writing a letter to a friend, briefly described the conditions on Wapato Island. His letter reads in part,

. .a mortality has carried off to a man its
[native] inhabitants and there is nothing to
attest that they ever existed except their
decaying houses, their graves and their unburied
bones of which there are heaps.

The Chinookans attributed this particular epidemic to an American, Captain John Dominis of the brig Owhyhee, who the natives suspected threw the disease agent into the Columbia River. The quarrel which precipitated this action was supposed to have been the disagreement between McLoughlin at Fort Vancouver and Dominis' direct trade with the natives surrounding the fort. The natives crowded around the fort because they knew the Chief Factor would bury them if they died of malaria. ${ }^{86}$ The malaria epidemic spread to the Dalles in 1831 reducing the Wasco 
and Wishram populations. Possible sources of infection at this time could have been the HBC fort near the Dalles or the Bache trading post mentioned earlier. ${ }^{87}$

The traditional native responses of sweat bathing to intervene in medical crises was no more harmful than the clinical problem; however, the subsequent phase in the treatment required a plunge in the river which was inimical to the sufferer's health. The sudden change in temperature caused innumerable natives to succumb. Dr. John Townsend and Father de smet noted the fatal effect this last step had on the afflicted population. In November of 1832 Nathaniel J. Wyeth remarked that the "Indians [near Fort Vancouver] are much reduced" most likely due to malaria. Farnham reported that the "epidemic fever of 1832. . almost swept [the Fort Vancouver] portion of the Columbia valley of its inhabitants. . . ." McLoughlin estimated that 90 percent of the native population occupying Sauvie and Deer islands

\footnotetext{
${ }^{86}$ Rich, Dr. John McLoughlin, Letters 1829-1832, 140; Wyeth, Journals, 149.
} 
succumbed to disease by 1833. Dr. Townsend was gloomier in his estimate that 99 percent of the Chinookans had died in the same period. Abandoned villages from the Cascades to Oak Point stood as a reminder of the once vital culture that had been almost obliterated. Those villages closer to white settlements were more seriously affected than those insulated by distance. ${ }^{88}$

with deadly swiftness malaria overcame its victims. Again, in traditional native response, those who were spared the initial symptoms fled to affiliated villages only to carry the scourge with them. De smet noted in his journal that,

.at that period [1830] the country
bordering on the columbia was visited by a fatal
scourge which carried off nearly two-thirds of
the inhabitants. It showed itself in the form
of an infectious fever, which threw the
individual into a state of tremor, and produced
such a burning heat throughout the body, that
the patient would sometimes cast himself into
the water to obtain relief. The population of
entire villages was cut off by this terrible
pestilence. Other villages were burnt in order

\footnotetext{
${ }^{87}$ Boyd, Introduction of Infectious Diseases, 121.

88 Pierre Jean De Smet, S.J. Oregon Missions and

Travels over the Rocky Mountains, in 1845-46 in Reuben G. Thwaites. ed., Early Western Travels: 1748-1846, vol. 2 . (Cincinnati: The Arthur H. Clark Company, 1907), 122.
} 
to arrest the infection which would have arisen from the pile of dead bodies that were left unburied. ${ }^{89}$

Malaria visited the Fort each succeeding year, taking more victims until Dr. John $K$. Townsend was successful in treating a Chinookan girl with quinine in 1834. Having used all his quinine supply he substituted an extract boiled from the bark of dogwood (Cornus nuttali), effectively curing others who came to the fort for help. ${ }^{90}$ In 1847 four villages of Chinookans on Sauvie Island were wiped out so swiftly there was no one left to bury the dead. The great Multnomah chief Casino, who resided close to Fort Vancouver at the mouth of the Willamette, was not immune to the effects of the malarial outbreak. "[H] is own immediate family consisting of 10 wives, 4 children and 18 slaves, being reduced in one year to one wife, one child and two slaves." 91

\footnotetext{
${ }^{89}$ De Smet, Oregon Missions, 122.

90 De Smet, Oregon Missions, vol. 2. 122; Corning, Dictionary, 75; McLoughlin, Letters 1829-1832, 163; Wyeth's Oregon and Townsend's Narrative, vol. 21, in Thwaites, ed., Early Western Travels. 342-44; Quoted from Vogel, 109-110; Farnham, Narrative, 67.

91 Kane, The Columbia Wanderer, 21.
} 
As smallpox and malaria claimed more and more victims, the ability of the survivors to continue their annual subsistence rounds was compromised. The increased distribution of labor among men and women was overwhelming for those who survived. With fewer men available to fish and women to gather roots, nuts and berries, the Chinookans finally consolidated their remaining families.

The Multnomah Chinookans at Fort Vancouver and Sauvie Island were exposed to whites and their diseases on a more continuous basis than those of the Dalles. Yet, with the establishment of the short-lived American trading post at the Dalles and subsequent competitive HBC post across the Columbia River in 1825, the Wasco and Wishram were exposed to the smallpox contagion that swept through their midst like wildfire. Malaria had a minor impact on the Chinookans east of the Cascades due to environmental conditions. The slow moving water and stagnant pools were not as readily available east of the Cascade Mountains.

By 1841, the Multnomahs had lost 98 percent of their total population to smallpox, malaria, dysentery, or other 
diseases. In contrast, the Wasco and Wishram suffered a loss of 74 percent. I attribute this difference to three factors: one, to the closer proximity of natives to a fluctuating and somewhat transient white population at Fort Vancouver; two, to a more hospitable breeding environment for $A$. malcupennis mosquitoes on sauvie Island; and three, to the Wasco and Wishram moving away from the river during the summer months to collect fruit and roots, thereby removing themselves from any contact with infected people or mosquitoes. 
The Missionary Era:

Stresses on Chinookan Culture and Belief Systems

"Look at the picture, half a century old!

Four painted savages, not athirst for gold;

Nor by ambition or revenge impelled,

stand pleading where the tide of traffic swelled,

By the Missouri's mighty, restless flood!

They seek the Christian's book, the white man's God"

A.T. Hawley, $1880 .{ }^{92}$

Following in the footsteps of the fur trading companies were men and women whose Christian faith prodded them to do good deeds among the natives of the Columbia. Prior to the influx of missionaries to the Columbia River explorers and traders had introduced the basics of Christianity to the Chinookans. Now came the Protestant missionaries who demanded obedience to God in addition to the white man's law. Many missionaries stood in contrast

92 Myron Eells, History of Indian Mission on the Pacific Coast. Oregon, Washington and Idaho (Philadelphia: The Union Press, 1882), 17. 
to their predecessors who were more tolerant of lifestyle differences between themselves and the natives. ${ }^{93}$

Responding to the religious revivalist movements that swept the nation in the early 19th century large numbers of missionaries searched for an outlet for the wellspring of faith that grew within them. While many went to exotic places overseas, a significant number chose to proselytize closer to home in the Pacific Northwest. Feeding this surge of religious evangelism was the Christian Advocate and Zion Herald article dated March 1, 1833, of the four Nez Percé who traveled to st. Louis, Missouri in September, 1831, presumably asking for religious instruction and teachers. Many Americans believed it was the natives' cry for salvation, asking the Americans to "come over and help us." The missionaries saw their role as one of civilizing the Indians by converting them to Christianity, as well as "[teaching] the Indian the use of letters, [training] them - . as farmers and mechanics, and [preparing] the way for the present higher cultivation 
and better domestic life." The missionaries' goals were to strip the natives of their own 'heathen' life-styles and civilize them through indoctrination of Christian virtues, principles and work ethic. ${ }^{94}$

In 1838, The Oregonian, and Indian Advocate succinctly expressed the motive of the missionary movement to the Pacific Northwest. The first volume declared that the native culture

- . must cease to be an Indian society. The tribes, as such, must become extinct, and a new organization must take their place, in which there shall be found white men and their rights, to an extent sufficient to secure the respect of civilized nations, and thus the safety of their own community. ${ }^{95}$

The recurrent theme in missionary writings and rhetoric was "[t]o save the Indian, they must be brought to settle upon and cultivate their lands . . . " The missionaries were charged with dismantling the Chinookans' culture,

94 Cornelius Brosnan, Jason Lee, Prophet of the New Oregon (New York: The Macmillan Company, 1932), 3; Francis Haines, "The Nez Perce Delegation to st. Louis in 1831", in the Pacific Historical Review, vol. 6, 1937, 71; Eells, History of Indian Mission, viii, xi.

95 The Oregonian, and Indian's Advocate, vol. 1, no. $1,1838,29$. 
settling the natives on a plot of land, and teaching them animal husbandry, and tilling the soil. The Presbyterian missionaries of the Board of Foreign Missions (BFM) were to

- go to the poor pagans and with Christlike simplicity, inform them of what they are by nature; what they have made themselves by sinful practice; and what they must be by the grace of God, or eternally perish. ${ }^{96}$

Fortified with this additional inspiration, the Protestant missionaries sallied forth on the field of heathenism to do battle with ignorance and idolatry.

Essential to this discussion is the comparative definition of religion. Webster defines religion as "belief in and worship of God or gods; a specific system of belief, worship, etc. often involving a code of ethics." The Chinookans performed rituals for a number of life events (first salmon, first elk, first fruits, first

96 The Oregonian, and Indian's Advocate, vol. 1, no. 2, 1838, 54; The Oregonian, and Indian's Advocate, vol. 1, no. 1, 1838, 29; Michael C. Coleman, Presbyterian Missionary Attitudes Toward American Indians, 1837-1893 (Jackson: University Press of Mississippi, 1985), 35. 
menses, naming ceremonies, ear piercing ceremonies, spirit quests, birth, death), which may be construed as religious ceremonies. The Multnomahs, Wascos and Wishrams' collective belief system provided a code of ethics and mores, based on spiritual values. Most of these values were taught by the extended families, and were related during the winter ceremonies through story telling. In the sense of a belief system and code of ethics, these cultural traits constitute a system of religious behavior. ${ }^{97}$

Neither the Chinookans at the Dalles nor those residing close to Fort Vancouver had an organized religion that matched the Euro-American experience prior to contact. As late as 1845, when Pierre Jean de Smet, S.J., took up residence among the Chinookans, he noted that [a]mong the aborigines of Oregon there is no trace of any religious worship. They have a belief which consists in certain obscure

\footnotetext{
97 Webster's New World Dictionary (Warner Books Paperback Edition, 1990.), 497; Ramsey, Coyote was Going There 135; Cox, The Columbia River, 171-2; Spier and Sapir, Wishram Ethnography, 267-8; Ramsey, Coyote Was Going There, passim.
} 
traditions; but no external forms of religion are visible among them. ${ }^{98}$

Father de Smet had observed Chinookan ceremonies and traditions that fostered cultural continuity. He was careful, however, to recognize that these were not religious practices as in his personal Euro-American experience. James Swan echoes de Smet's observations by writing in his journal that the Chinooks

- . do not, as is generally supposed, address a Great Spirit, neither do they believe in one overruling almighty maker of the world and all things contained therein; consequently, they do not address themselves except to their own private Tománawos [guardian spirits.] Their heaven is in the centre of the earth, which they believe to be hollow, and there all is happiness. ${ }^{99}$

Chinookan Belief Systems

A survey of the Chinookans' belief system is required to more clearly understand the cultural environment in which the missionaries worked. The Chinookans held all of nature to be sacred, with specific animals and mythic 
beings holding a central position in their culture. Stories and legends told during the winter months perpetuated the cosmological mythos, and provided moral instruction and cultural continuity.

The "spirit quest" was an integral part of the Chinookans' culture and entailed the discovery of a power within each individual that would guide the person through his or her lifetime. The quest was a culmination of years of preparation to prepare the youth to accept the guidance of powerful entity. The spirit quest is fundamental to many Native American cultures and noted in the literature addressing native religious custom in the Pacific Northwest: A more detailed description follows.

Following years of physical and mental preparation, individual pubescent boys and girls from both the Dalles and Sauvie Island villages would go on a quest to acquire a guardian spirit. The quest was performed over the course of several, usually five, nights. (The number five was significant in Chinookan culture.) The youth and his 
family hoped he would encounter a spirit in the form of an animal or object that would imbue the youth with power and special characteristics. Returning to the village after five days of fasting and living in the open without shelter, the youth was typically faint and would fall into a trance. An elder of the village would revive the youth in a symbolic rebirth and reintroduce him to society with a new name. Spirit quests were a young person's endeavor to identify a place within the village community, to assume the strength and beneficial qualities of the object or animal that the youth saw in a dream or vision. Swan wrote that youths who succeeded were esteemed as the more competent and skilled craftsmen among the villagers, or became shamans. According to Chinookan belief the spirit would adopt the youth, teaching him a secret song and dance to be performed during the winter season ceremonies. The identity of the spirit was never divulged until on one's deathbed, yet an individual would identify his or her guardian spirit in other ways. The refusal to eat deer meat or salmon, or wear the skin of the guardian 
spirit helped observers determine the guardian spirit of a fellow villager. ${ }^{100}$

It was possible to acquire more than one guardian spirit. In the Wasco story of "The Big-footed Man and His Son" the boy's mother implores him to acquire as many guardian spirits as possible so he could defeat his cruel father. After many days the boy returned to his mother claiming that five thunders and lightning, five bands of grizzly bears, five bands of elk, five whirlpools, five long-legged water spiders, and five bands of yellow flies had all given him their strength and special power. Conversely it was also possible that the young person never acquired a guardian spirit. In that case, he or she could look forward to a mediocre life among the villagers. ${ }^{101}$

The belief of acquisition of powers from the natural world is supported through the studies of the Wasco and Wishram by Edward Sapir during the 1920s. Sapir reports

\footnotetext{
100 George Gibbs, "George Gibbs' Account of Indian Mythology in Oregon and Washington Territories" in the Oregon Historical Quarterly, vol. 57, no. 2, 1956, 140; Swan, The Northwest Coast, 171.
} 
that animals, reptiles, insects and fish were entities from which power could be obtained. Those who had sturgeon spirits were exceptionally brave; mountain lizards, snakes, small insects and small birds bestowed stealth; deer and elk spirits helped hunters locate and kill game. Even imaginary beings could imbue power.

Once a person had acquired a spirit he or she was capable of understanding the language of that particular spirit. The abuse of that power could result in the spirit abandoning the person. An example of this is found in "The Elk, the Hunter, and His Greedy Father." The rituals of story-telling seem to have been less infused with sacred purpose and more concerned with moral and existential education. This wasco tale is a message of respect and lessons to be learned from their Tománawos (spirit guides.) ${ }^{102}$

The Reverend Henry Kirk White Perkins, Methodist Episcopal missionary at the Dalles, noted in his journal dated August 26, 1843, that according to Wasco mythology, 
all the animals, insects, and lizards were once human. In their animal form they were possessed by the spirits of people who lived before according to their individual character. The Wasco and Wishram believed that animals of prey possessed the spirits of legendary warriors. ${ }^{103}$

There seem to have been two classes of spirits, good and evil. At the Dalles the good spirit was called tah and the evil spirit was called skep (pronounced scape). If a person was suddenly taken ill he was supposed to be possessed by a skep. Only a more powerful tah could rid him of the skep. Having been cured by the spirit the patient makes an image of his guardian tah and keeps it in a secure place so no one will discover it. This image is called a pat-ash. Closer to Fort Vancouver, Alexander Ross reported that "[the Chinookans] acknowledge a good and a bad spirit, the former named Econe, the latter Ecutoch."104

\footnotetext{
102 Sapir and Spier, Wishram Ethnography, 236-239, passim; Ramsey, Coyote Was Going There, 64-65.

103 Henry K.W. Perkins, "Journal" in Robert Boyd, ed., People of The Dalles, 282 .

104 Henry K.W. Perkins, "Journal" in Robert Boyd, ed., People of The Dalles, 282; Ross, Adventures, 110.
} 
The Chinookans at the falls of the willamette believed that coyote, a creature with mythical powers, could defeat an evil spirit or skookum. In "The Skookum's Tongue," Coyote was angry that a skookum had eaten all the people of the village. In revenge, coyote cut off the skookum's tongue and buried it under the rocks near the falls. The villagers, no longer threatened by the skookum, returned to the village. A clever person could outwit a skookum as well. ${ }^{105}$

Imbued with spirit power Multnomah, Wasco and Wishram youth found strength and guidance for their daily lives, a place within the organization of the village, and in some cases, a vocation. 


\section{American Religious Attitudes in the 19th Century}

The general American population fused Christianity with civilization. As a result of the melding of these two distinct ideas Americans looked upon the Columbia River natives as being uncivilized due to their 'heathenism.' How easy it must have been to believe one's mission was to simply elevate the Indian race through Christian settlement of Oregon, being separated from the maelstrom by 3,000 miles. ${ }^{106}$

Following those principles the missionaries strove to imbue in the natives of the Columbia River those virtues of Christianity and civilization that the evangelists believed would remedy the perceived abject poverty and ignorance of the Chinookans. The missionary societies expected their people to live among the Chinookans in order to provide a model of Christian life and civilization. At the Dalles, Alvan F. Waller and Perkins did just that. The Catholic priests were not far behind the Methodists. By 1844 the Catholics had established St.

\footnotetext{
${ }^{106}$ The Oregonian, and Indian's Advocate, vol. 1, no.
} 1,27 . 
Mary's convent and school on the Willamette, run by the Sisters of Notre Dame, to minister to the peoples, both white and native, who turned to them. Father De Smet and Father Blanchet made the rounds to their respective flocks, hoping to influence them to follow the Catholic religion. By 1846 there were 12 Catholic priests seeking to turn the natives of the oregon Territory to the "true faith." Among the Missionary societies on the east coast there was a lively debate as to the most efficacious method for bringing native Americans to enjoy the fruits of American society and the blessings of Christianity. These ratiocinasts had little concept of the conditions to be encountered along the Columbia River other than the romantic prose and self-aggrandizing sophistry from the journals of Wyeth, Franchère, Anderson, Irving, and others. This ignorance did not stop the Missionary Boards from devising policies that would impede the progress and occasionally threaten the lives of those they charged with

\footnotetext{
${ }^{108}$ De Smet, Oregon Missions and Travels, vol. 1, 16.; Robert F. Berkhofer, Jr., Salvation and the Savage, An Analysis of Protestant Missions and American Indian
} 
success. Nor were these evangelistic idealists impeded by the widely held philosophical position that in the realm of salvation, the indigenous peoples were inherently different from whites. ${ }^{108}$

Into the unknown and little explored oregon country, and with little forethought or planning, the Missionary Society of the Methodist Episcopal Church sent men and women who were willing to dedicate their lives to the mission of civilizing the "heathen." The Methodists were the first to send a complement of newly ordained ministers and lay leaders to the Oregon territory to 'civilize' the natives, and bring spiritual guidance to the traders and trappers. Joining the Wyeth expedition from Boston in 1834, the Reverend Jason Lee set out to establish a mission in the Columbia country. His first mission, founded in 1834, was the Willamette Mission near modern Salem along the willamette River. There he ministered to the Calapooya on the edge of French Prairie, and traveled

Response, 1787-1862 (Lexington: University of Kentucky Press), 7-8, passim; Lowenberg, Equality, 240-241. 
downstream to Fort Vancouver to preach to the Multnomahs. ${ }^{109}$

At the Dalles the Reverends Henry Kirk White Perkins and Daniel Lee, Jason Lee's nephew, arrived by canoe on March 22, 1837, to embark upon their mission to the Chinookans and Sahaptins. Their mission was built about a mile from the river with a farm to raise produce and livestock. Rev. Alvan F. Waller joined Perkins in 1844, having first founded a mission at Oregon City in 1840. Perkins, Lee, and Waller 'rode the circuit' of native villages, visiting each one in turn, and returning home to teach their own families. ${ }^{110}$

The Catholic Church followed the Methodists' example by sending Fathers Modest Demers and Francis Norbert Blanchet to the Oregon territory in 1838. They arrived in Fort Vancouver on November 24, 1838, the first "black gowns" in Oregon. The Methodist's "Great Reinforcement" arrived at Fort Vancouver on June 1, 1840, in which Jason

\footnotetext{
109 Lowenberg, Equality, 80 .

110 Loren Brown Hastings, Journal, (University of Washington, Suzzalo Library, VF 55), 31; Corning, Dictionary, 257; Waller MSS, fol. 11.
} 
Lee returned from the east with a total of 49 settlers and members for the Methodist Mission. Father L. Rosseau established the Catholic mission, st. Peter, across from the Methodists on Mill Creek near the Dalles on May 16, $1848 .{ }^{111}$

Jason Lee's primary reason for settling on the Willamette was to influence the white traders who had taken native wives. In 1839, Farnham described the missionaries as being of that "zealous class of Protestants called Methodist Episcopals." After four or five days in their care Farnham identified their purpose in Oregon as civilizing and christianizing the natives, while ministering to the whites in the region. Lee's strategy was to use the traders and their wives as examples to the surrounding Chinookans. Lee thought it

\footnotetext{
Alvan M. Josephy, Jr., The Nez Perce Indians and the Opening of the Northwest (Lincoln: University of Nebraska Press, 1971), 118; C.C. Royce, Indian Land Cessions in the United States (Washington: Government Printing Office, 1900; reprt. New York: Arno Press, 1971.), 813; Corning, Dictionary, 103; Luther Cressman, "Cultural Sequences at the Dalles, Oregon" in Transactions
} 
was essential that "[the traders] influence must be corrected" to serve as an example for the natives. Lee recognized that white settlers with native wives had great authority with their native relatives. He hoped to exploit that influence for missionary ends by winning the confidence and souls of the settlers and then using it to convert the natives. ${ }^{112}$

Shortly after the arrival of the Catholic priests there ensued a rivalry between the Catholic and Methodist missionaries for the souls of the natives. Alvan Waller lamented that with the abandonment of the Fort George mission by two Methodist colleagues the Chinookans would "probably at length fall into Catholicism." Three weeks later he wrote, "Found that the Catholic priest had been down in my absence endeavoring to set the Indians against me giving them beads with crosses attached to them \&c."113

of the American Philosophical Society, vol. 50, part 10, $1960,40$.

\footnotetext{
112 Farnham, Narrative, 22.

113 Waller MSS, fol. 11.
} 
Conflicts between Missionary and Native Societies

A major stumbling block to proselytizing was the fact that few of the missionaries could preach in the native vernacular. At the Dalles Perkins and Lee endeavored to instruct the local natives in their own language, struggling to learn the native languages. ${ }^{114}$

The missionaries endeavored to change the whole of Chinookan society, not realizing the impact it would have on the native culture in general and the people in particular. First and primary to the missionaries was the subject of slavery among the Chinookans. The ubiquitous possession of slaves among the Chinookans was abhorrent to the missionaries as well as the Chief Factor at Fort Vancouver, although some of the HBC's employees held slaves, as did some of the retirees. Perkins identified himself as "an immediate abolitionist". Casino, chief of the Multnomahs near Fort Vancouver, possessed 18 slaves, Tamakoun just below the Dalles had slaves. Perkins and Waller both exhorted the natives to free their slaves as $33-34$ 
an act of Christian charity. Of course the Chinookans were loath to discard this very conspicuous form of wealth. Perkins noted his displeasure regarding slaveholding among the Columbia River natives. In his journal dated August 19, 1843 he wrote,

- .all we could do, was to remonstrate with [the Chinookans] on their return [from purchasing slaves] upon the wickedness of their course. This, some resented, \& would not be convinced that the traffick in slaves was a "moral evil".

His interference with the trafficking incurred the wrath of many of the Wasco and Wishram traders. After lecturing the group on the sinfulness of holding slaves Perkins returned to his home only to be confronted by angry natives, one of whom tied Perkins to a chair, threatening to whip the missionary. Another native proceeded to argue that slaves were their money and would never relinquish holding them.115

Farnham, Travels, 360; Boyd, People of the Dalles, 33-34, 85, 90, 276; Lee and Frost, Ten Years in Oregon, 133; Kane, Incidents of Travel on the North-West Coast, 21; Spier and Sapir. Wishram Ethnography, 225; Hodge, Handbook of American Indians, 273; Elliott Coues, ed., New Light on the Early History of the Greater Northwest: The Manuscript Journals of Alexander Henry, Fur Trader of the 
The missionaries also frowned on the plural marriage custom of the Wasco and Wishram. Washington Irving reported that a chief "possesses but little authority unless he be a man of wealth and substance--that is to say, possessed of canoe, slaves, and wives. The greater the number of these, the greater is the chief." Gabriel Franchère's observations corroborate those of Irving. In his journal Franchère notes that a village chief is measured by his wealth: ". . . a chief has a great many wives, slaves and strings of beads. . . ." To dispense with their slaves and additional wives would reduce the wealthy elite to the level of commoners. Again, the thought of confining themselves to a single wife was a distasteful prospect for people who valued their elite position within the village. As late as 1871 the Wasco

North West Company, and of David Thompson . . 1799-1814. - . 3 vol. (New York: Francis P. Harper, 1897), $787,794,838$, passim; Rich, The Letters of Dr. John MCLoughlin, 58 . 
practiced polygamy, though they were confined to the Warm Springs reservation. ${ }^{116}$

Despite the moral conflicts there were many aspects of Methodism that appealed to the Chinookans. The primary allure was the communal participation of worship. The length of revivals and camp meetings was similar to that of traditional native winter ceremonies. The significance of this timing is that the Chinookans were gathered in their permanent villages during the winter months. Christmas celebrations were held during the winter months as were the five-day spirit dances and native winter ceremonies. Both the native winter ceremonies and the week-long camp meetings gathered the people in one enclosed area and delivered the messages in a condensed time frame that induced heightened emotional states. Each held solemn significance to the participant, as well as high entertainment and illustration for the observer. Lent and Easter observances by the Methodists coincided Voyage, 329; Ramsey, coyote Was Going There, 54. 
with Chinookan first salmon ceremonies in the spring. Another similarity was the spiritual rebirth of converts, reminiscent of the rebirth experienced by a successful spirit quest (see page 91.$)^{117}$

Perkins and Lee's low-key delivery style permitted the natives to adopt specific portions of the lessons. Both men also represented the mission as leaders, similar in status as the village chiefs. They invited the chiefs to participate in the meetings which bestowed prestige on the native leaders. Another parallel was that in Chinookan culture proclamations were given to a crier who relayed the chief's message. In the early part of their mission both Lee and Perkins used translators to make themselves understood. Lee and Perkins acted like village chiefs and were treated as such. ${ }^{118}$

However, the philosophical distinctions between the Chinookan and Christian belief systems were difficult to overcome. The Methodists separated their spiritual and temporal functions, compartmentalizing the two. God lived

117 Spier and Sapir, Wishram Ethnography, 241.

118 Boyd, People of the Dalles, 211. 
apart from the whites in a place called Heaven. This distinction was not made in the native belief. The Tománawos were a part of the Chinookans. ${ }^{120}$

There was some confusion expressed by the Chinookans at the Dalles regarding the bitter rivalry between the Methodist missionaries and itinerant Catholic priests. On the face of it both faiths professed belief in the same God, although their ritualism and conventions differed. This was a source of confusion to the natives, one that was not easily explained away by the two factions. Waller writes of it in his journal dated January 29, 1841. Pohpoh, one of the recently converted Dalles Indians, visited Waller that evening. Waller claims that the priest's visit with Poh-poh "very much disturbed [Poh-poh's] mind giving him papers beads curiously wrought \&C, All calculated to prejudice his mind against us and the protestant religion."121

120 Loewenberg, Equality on the Oregon Frontier, 237. 121 Waller MSS, fol. 3. 
Regardless of which religion the Chinookans chose to follow, the idea of the natives embracing Christianity in its entirety while discarding a belief system generations old is difficult to comprehend. Instead I believe there were ulterior motives behind the natives' ready acceptance of the rituals and external features of each faith. Being driven by a desire to accumulate wealth, and seeing the whites with an abundance of material goods, it is logical to assume that the Chinookans sought to acquire the same goods by whatever means possible. Adopting another powerful spirit was nothing more than expanding their cultural repertoire of Tománawos. This accretion of another spirit further demonstrates the plastic nature of Chinookan culture as discussed in the first chapter. With an imperfect delivery system (Chinook Jargon) used to transmit the very symbolically and metaphorically complex social and cultural messages engendered in Christianity, I believe the native recipients of this message failed to understand that they were adopting a formalized religion with its accompanying social mores and implicit legal foundation. This is supported by a comment in Reverend 
Joseph H. Frost's journal that, after introducing himself to the Chinookans they

. . manifested a degree of disappointment when I informed them . . . that my principal design was to teach them how to worship the Great Chief above, and not to trade for beaver or salmon, only so much as we might need for food. For it should not be forgotten that they never act from any higher motives, in their transactions with the whites, than the prospect of temporal gain; and it is perfectly reasonable that they should not, since they possess no correct knowledge of the relation they sustain to God. ${ }^{122}$

The proposed conversion of the Chinookans by direct contact with them and indirectly by means of the settlers' examples of Christian living did not resolve the Missionaries' dilemma of how best to bring their message the Chinookans. While the objective was to link the Native and the civilized worlds, after the first major emigration of settlers in 1843 the tendency was to separate the two groups spatially.

By 1835 the remnant of Multnomahs who survived the various waves of diseases sweeping the lower Columbia 
River had been displaced by white traders who settled Sauvie Island and its environs. Lieutenant Charles Wilkes, surveying the Oregon Country for the U.S. Government, observed in 1839 that the missionaries of the Willamette valley had made more progress in farming and settling their claims than in Christianizing the natives. Thomas Farnham corroborated Wilkes's observations by commenting,

"Little has yet been effected by them in
christianizing the natives. They are
principally engaged in the cultivation of the
mission farms, and in the car of their own
stock, in order to obtain flocks and herd for
themselves, most of them having selected lands.
As far as my personal observations went, in the
part of the country where the missionaries
reside, there are very few Indians to engage
their attention; and they seemed more occupied
with the settlement of the country and in
agricultural pursuits than in missionary
labours." ${ }^{23}$

At the Dalles, the Methodist missionaries, Perkins and Daniel Lee, nephew of Jason Lee, continued to minister to the Wasco and Wishram with limited success. Waller noted in a letter to Daniel Lee that "We are doing very little

${ }^{123}$ Wyeth, Correspondence, 149; Farnham, Narrative, 101 . 
in a direct way to save our people." Waller recognized that the chores required to keep his mission together deprived the Wasco/Wishram of his attention to their spiritual salvation. He complained bitterly of the lack of support from the Missionary Board to his colleagues and family back east. Daniel Lee commiserated: in a letter dated July 12, 1841 Lee wrote to Waller from Wascopan complaining that there was so much to do to feed and house their mission group, there was little time left to visit the Chinookans. Perkins was disappointed to discover that the Wishram women were not praying as much as he would have liked, as they were employed in the annual task of drying salmon. He did mention that the more frequently he visited the natives, the better it was for the wasco and Wishram's collective salvation, and for his personal satisfaction. Yet, Perkins was disappointed and said so to waller. Although he had traveled a good deal among the natives on his circuit Perkins was discouraged at their lack of progress to a more civilized culture. The missionaries still perceived the Wasco and Wishram as being poor because of their few and skimpy garments. 
Jason Lee noted in his journal on October 15, 1840, that "[t]hese Indians are extremely poor, many of them not having clothes and skins enough, all told, to cover their persons from the falling rain. . . " This should be viewed in the context of the aftermath of smallpox and malaria epidemics that had recently swept through the area in the previous decade. Their numbers were drastically reduced, leaving little time to do more than provide food subsistence for the remnant population. ${ }^{124}$

Despite the success of the Camp Meetings in 1840, both Perkins and Daniel Lee began to doubt the effectiveness of their ministry. To all appearances, the Wasco and Wishram were very attentive during the missionaries' visits, yet in their absence the Chinookans were content to follow their traditional lifestyle. ${ }^{125}$

Waller described the difficulty he encountered in spreading the word, having to wait for four separate interpretations to go through the assembly at the Dalles.

\footnotetext{
${ }^{124}$ Boyd, People of the Dalles, 206-7; Waller MSS, letter from Alvan Waller to Daniel Lee, October 19, 1841, fol. 7, letter from Daniel Lee to Alvan Waller, July 12, 1841, fol. 1 .
} 
He had learned the Chinook Jargon and continued to depend on its limited vocabulary to express the complicated ideas of Christianity and civilization. Despite his four years residence in Oregon, Waller consistently failed to recognize the reason why he was visited so frequently in his home and "begged" for some small article. This was the traditional way the Wasco and Wishram cemented bonds of friendship with friends and trading partners, yet the missionaries saw it as a nuisance. It appears from Waller's journal that he was pleased to have the Chinookans come to him so he could enlighten them with his faith, or show them how to tend a garden but a reciprocal flow of information was not welcome. ${ }^{126}$

Overall the Methodist experiment in Christian philanthropy toward the natives of the Columbia River was a miserable failure. Thirty years after the systematic introduction of Christianity to the Chinookans, in 1852 
James Swan observed that the missionaries had failed in their quest to convert the Chinookans. He wrote that

[t]he Indians can see but little or no difference between their system of Tománawos and our own views as taught them. For instance, the talipus, or fox, is their emblem of the creative power; the smispee, or duck, that of wisdom. And they say that the Boston people, or Americans, have for their Tomanawos the wheark, or eagle, and that the King George, or English people, have a lion for their Tomanawos. ${ }^{127}$

From this description it is clear that the Chinookans were open to the adoption of additional spirits within the realm of their experience, but they did not understand that the adoption of Christianity was to supercede their native religions. The Missionary Society of the Methodist Episcopal Church responded to reports of incompetence and waste by closing the Vancouver Mission in April 1844, and consolidating the remaining two missions. In 1847 the station at the Dalles was transferred to the American Board of Commissioners for Foreign Missions, and thus that episode of the Methodist Episcopal Church's missionary work was brought to a close. Those missionaries who chose 
to remain in oregon turned to preaching to white settlers and retired $H B C$ trappers farther up the willamette in Salem. 


\section{Conclusions}

Over the course of 2,000 years, the Wasco and Wishram of the Columbia River had established a network of kinship and commerce that defined, reinforced and enriched their culture. Each village was an autonomous unit with ties securely established among distant peoples through marriage and trading partnerships in which there was an exchange of goods and services.

Unlike other native groups east of the Rocky Mountains who greeted explorers and settlers in the $16^{\text {th }}$ century, the Chinookans had little experience with EuroAmericans prior to the end of the $18^{\text {th }}$ century. It was not the superior technology of firearms and steel tools, or lack of unity among the Chinookans that crippled the rich native cultures along the Columbia River. Instead it was the insidious effect of introduced diseases that tolled the death-knell for this culturally rich people. The devastating diseases that wiped out villages had more impact on the Chinookans than any other factor introduced by the whites. Given time to acquire immunity to alien diseases, the eastern woodlands natives had recovered 
their pre-contact numbers when the infant nation wanted to expand into their territory. Pawnee, Cherokee and Navajo peoples of the southeast were able to resist, physically and legally for a limited time, the push of settlers into their lands. This was not the case with the Chinookans. The Wasco/Wishram were overwhelmed in the short span of 75 years. When white settlers arrived in the oregon Territory in the mid-19 th century, they discovered a land that had once supported many thriving cultures, now barren of indigenous people.

Euro-American traders inadvertently introduced European diseases into the 'virgin soil' population of the Chinookans with a detrimental outcome. Smallpox swept through the native peoples with ferocious efficacy, leaving a remnant cohort to greet Captain Vancouver in 1792, and the Corps of Discovery in 1805-06. After a respite of about a generation, malaria struck the Chinookans in 1829. This last epidemic was nearly the Coup de Grace for the surviving Chinookans.

The combined stresses of contact with Euro-Americans (the introduction of diseases for which they had no 
immunity; technology, and cultural expectations viz a viz trade relations; the affect of missionary efforts to strip the Chinookans of their belief systems) upon native populations was to undermine the cultural infrastructure of the native groups.

By the third decade of the 19th century, native populations on Sauvie Island had completely disappeared as a direct result of white-introduced diseases. In the end, the economic and cultural stress induced by Euro-Americans upon the native populations notwithstanding, the effects of Euro-American diseases upon a vulnerable native population destroyed the natives in measures that economic and cultural upheaval cannot begin to equal. 
Bibliography

Allen, A.J. Ten Years in Oregon: Travels and Adventures of Dr. E. White and Lady, west of the Rocky Mountains. Ithaca: Press of Andrus, Gauntlett \& Co., 1850 .

American Board of Commissioners for Foreign Missions. Oregon Mission. 2 vols., 1843-1859.

Ames, Kenneth M. "The Northwest Coast: Complex HunterGatherers, Ecology, and Social Evolution" in Annual Review Anthropology, 1994 (23): 209-229.

Ames, Kenneth, Doria Raetz, Stephen Hamilton, and Christine McAfee. "Household Archaeology of a Southern Northwest Coast Plank House." Journal of Field Archaeology 19 (3):275-290.

Anderson, William M. The Rocky Mountain Journals of William Marshall Anderson. Edited by Dale L. Morgan and Eleanor Toweles Harris. San Marino: The Huntington Library, 1967.

Bartlett, Irving $\mathrm{H}$. The American Mind in the MidNineteenth Century. New York: Thomas Y. Crowell Company, 1967.

Beckham, Stephen Dow. The Indian of Western Oregon: This Land Was Theirs. Coos Bay: Arago Books, 1977.

Berkhofer, Jr., Robert F. Salvation and the Savage: An analysis of Protestant Missions and American Indian Response, 1787-1862. Louisville: University of Kentucky Press, 1965. 1979 .

. The White Man's Indian. New York: Vintage Books,

Boas, Franz ed. "Chinook Texts." Smithsonian Bureau of American Ethnology, Bulletin 20. Washington: Smithsonian Institution, 1894. 
Boyd, Robert $\mathrm{T}$. The Introduction of Infectious Diseases Among the Indians of the Pacific Northwest, 17741874, Ph.D. dissertation, University of Washington, 1985 .

Boyd, Robert and Yvonne Hajda. "Seasonal Population Movement Along the Lower Columbia River: The Social and Ecological Context." in American Ethnologist 14, (May 1987): pp. 309-326.

Boyd, Robert. People of the Dalles: The Indians of Wascopam Mission. Lincoln: University of Nebraska Press, 1996.

Clayton, William. The Latter-Day Saints' Emigrants' Guide. Saint Louis: Missouri Republican steam Power Press-Chambers and Knapp, 1848; reprinted ed., Salt Lake City: Salt Lake Herald, 1897.

Cohen, Felix. Handbook of Federal Indian Law. Charlottesville: The Michie Co., 1982.

Coleman, Michael C. Presbyterian Missionary Attitudes toward American Indians, 1837-1893. Jackson: University Press of Mississippi, 1985.

De Smet, Pierre Jean, S.J. "Oregon Missions and Travels over the Rocky Mountains, in 1845-46." in Reuben G. Thwaites. ed., Early Western Travels: 1748-1846, Vol 2. Cincinnati: The Arthur H. Clark Company, 1907. pp. $109-424$.

Drucker, P. "Rank, Wealth, and Kinship in Northwest Coast Society." American Anthropologist 41 ():

Eells, Myron. History of Indian Mission on the Pacific Coast. Oregon, Washington and Idaho. Philadelphia: The Union Press, 1882 .

Farnham, Thomas Jefferson. "Travels in the Great Western Prairies, the Anahuac and Rocky Mountain, and in the 
Oregon Territory", in Reuben G. Thwaites, ed., Early Western Travels: 1748-1846, vol. $1 \& 2$, Cleveland: The Arthur H. Clark Co, 1906.

Fagan, Brian. Ancient North America: The Archaeology of a Continent. New York: Thames and Hudson, Inc., 1991.

Fort Nisqually Indian Shop Blotter, January 1, 1845 through December 31 1845. Typescript.

Garth, Thomas R. "Early 19th C. Tribal Relations in the Columbia Plateau" in SW Journal of Anthropology 20 (1964): 45-48.

Gibbs, George. Indian Tribes of washington Territory. Executive Document No. 91, H. of Rep., 33rd Cong., 2nd Session Reports of Exploration and Surveys, to Ascertain the Most Practical and Economical Routes for a Railroad from the Mississippi River to the Pacific Ocean....1846; reprinted, Fairfield, WA: Ye Galleon Press, 1967.

Gunther, Erna. Indian Life on the Northwest Coast of North America As Seen by the Early Explorers and Fur Traders during the Last Decades of the Eighteenth Century. Chicago: University of Chicago Press, 1972.

Hajda, Yvonne P. Regional Social Organization in the Greater Lower Columbia, 1792-1830. Ph.D. dissertation, University of Washington, 1984.

Harris, Cole. The Resettlement of British Columbia: Essays on Colonialism and Geographical Change. Vancouver: University of British Columbia Press, 1997.

Hodge, Frederick Webb, ed. Handbook of American Indians North of Mexico. 2 Vols. Washington: Government Printing Office, 1907.

Hosen, Frederick, E., ed. Unfolding Westward in Treaty and Law: Land Documents in United States History from the 
Appalachians to the Pacific, 1783 - 1934. Jefferson: McFarland, 1988 .

Howison, Neil M. "Report on My Travels to the Rocky Mountains" Methodist Quarterly Review. 1850

Hunn, Eugene S. Nch'i-Wana The Big River: Mid-Columbia Indians and their Land. Seattle: University of Washington Press, 1990.

Irving, Washington. Astoria. Portland: Binfords and Mort, 1950.

Jackson, Donald, ed. Letters of the Lewis \& Clark Expedition with Related Documents, 1783-1854. Urbana: University of Illinois Press, 1962.

Jacobs, Wilbur R. Dispossessing the American Indian. New York: Scribners, 1972 .

James, M. Annette, ed. The state of Native America; Genocide, Colonization, and Resistance. Boston: South End Press, 1992 .

Josephy, Alvan M., Jr. The Nez Perce Indians and the Opening of the Northwest. New Haven: Yale University Press, 1965.

Kane, Paul, The Columbia Wanderer, 1846-47: sketches and paintings of the Indian and his lecture, "The Chinooks" OHS, 1971, edited by Thomas Vaughan.

- Incidents of Travel on the North-West Coast, Vancouver's Island, Oregon, \&c., \&c. by Paul Kane, Esq. Toronto Read before the Canadian Institute, March 14, [ca. 1855]

Kinney, J.P. A Continent Lost - A Civilization Won: Indian Land Tenure in America. Baltimore: Johns Hopkins Press, 1937. 
Lavender, David. The Way to the Western Sea: Lewis and Clark Across the Continent. New York: Doubleday, 1988.

Lee, Daniel, and J.H. Frost. Ten Years in Oregon. New York: J. Collord, Printer, 1844.

Leonhardy, Frank C., and David G. Rice. "A Proposed Culture Typology for the Lower snake River Region, Southeastern Washington. Northwest Anthropological Research Notes 4 (Spring 1970):1-29.

Lewis, Meriwether, and William Clark. Letters of the Lewis and Clark Expedition with Related Documents, 17831854. Donald Jackson, ed. Urbana: University of Illinois Press, 1962.

Limerick, Patricia Nelson. The Legacy of Conquest. New York: W.W. Norton, 1987.

Loewenberg, Robert James. The Idea of Equality in Ante-Bellum America: Oregon a test case. Ph.D. dissertation, Yale University, 1972.

- Equality on the Oregon Frontier: Jason Lee and the Methodist Mission 1834-43. Seattle: University of Washington Press, 1976.

Mallery, Garrick. "Picture Writing of the American Indians." Tenth Annual Report of the Bureau of Ethnology to the secretary of the Smithsonian Institution. 1888-89. pp. 25-777. Washington: Government Printing Office, 1893.

- "Disuse of Sign Language." First Annual Report of the Bureau of Ethnology to the secretary of the Smithsonian Institution. 1879-89. pp. 269-550. Washington: Government Printing Office, 1880 . 
Marcy, Randolph B. The Prairie Traveler. A Hand-book for Overland Expeditions. New York: Harper \& Brothers, 1859 .

McConnaughey, Bayard H. and Evelyn McConnaughey. Pacific Coast. New York: Chanticleer Press, 1997.

Minor, Rick. Aboriginal settlement and Subsistence at the Mouth of the Columbia River. Ph.D. dissertation, University of Oregon, 1983.

Mitchell, Donald. "Predatory Warfare, Social Status, and the North Pacific Slave Trade." $23(1): 39-48$.

Mooney, James. "Myths of the Cherokee." Nineteenth Annual Report of the Bureau of Ethnology to the Secretary of the Smithsonian Institution. 1897-98. pp. 3-548. Washington: Government Printing Office, 1898.

O'Brien, Sharon. American Indian Tribal Governments. Norman: University of Oklahoma Press, 1989.

Oregon Archaeology Society. Indian Trade Goods. Portland, Oregon: Oregon Archaeology Society, 1993.

Parkman, Francis. The Oregon Trail. San Francisco: Holt, Rinehart and Winston, Inc. 1969.

Powell, Fred Wilbur, ed. Hall J. Kelley on Oregon. Narratives of the Trans-Mississippi Frontier. Princeton: Princeton University Press, 1932.

Price, Monroe E. Law and the American Indian: Readings, Notes and Cases. New York: The Bobbs-Merrill Co., Inc., 1973 .

Reichwein, Jeffrey C. Native American Response to EuroAmerican Contact in the Columbia Plateau of Northwestern North America, 1840 to 1914: An Anthropological Interpretation based on Written and 
Pictorial Ethnohistorical Data. Ph.D. dissertation. Ohio State University, 1988.

Rich, E.E., ed. The Letters of John McLoughlin, First Series, 1825-38. London: The Hudson's Bay Record Society, 1941 .

Roe, Michael, ed. Journal and Letters of Capt. Charles Bishop on the Northwest Coast of America, 1794-1799. Cambridge: Hakluyt Society, 1967.

Ronda, James P. Lewis and Clark among the Indians. Lincoln: The University of Nebraska Press, 1984.

Ross, Alexander. Adventures of the First settlers on the Oregon or Columbia River, 1810-1813. Cleveland: Arthur H. Clark, 1904; reprint, Lincoln: University of Nebraska Press, Bison Books, 1986.

Royce, C.C. "Investigations Relating to Cessions of Land by Indian Tribes to the United States" First Annual Report of the Bureau of Ethnology 1879-1880. Washington: Government Printing Office, 1881.

Indian Land Cessions in the United States. Washington: Government Printing Office, 1900; reprt. New York: Arno Press, 1971.

Ruby, Robert H. and John A. Brown. The Chinook Indian: Traders of the Lower Columbia River. Norman: University of Oklahoma Press, 1976.

Saleeby, Becky and Richard M. Pettigrew, "Seasonality of Occupation of Ethnohistorically-Documented Villages of the Lower Columbia River." Greengo, Robert E., ed. Prehistoric Places on the Southern Northwest Coast. Seattle: University of Washington, 1983. pp. 169193 .

Sapir, Edward. Wishram Texts. Vol. 2. Leyden, Holland: E.J.Brill, 1909. 
Silverstein, Michael. "Chinookans of the Lower Columbia" in Handbook North American Indians. Vol. 7, The Northwest Coast, Washington, D.C.: Smithsonian Institution, 1990.

Spier, Leslie and Edward Sapir. Wishram Ethnography. Seattle: University of Washington Press, 1930.

Stampp, Kenneth M. America in 1857. New York: Oxford University Press, 1990.

Strong, Emory. Stone Age on the Columbia River. Portland: Binford and Mort, 1959.

Suphan, Robert J. Oregon Indians II: Ethnological Report on the Wasco and Tenino Indians. New York: Garland Publishing, Inc. 1974 .

Suttles, Wayne. Handbook of North American Indians. Washington, D.C.: Smithsonian Institution, 1990.

Sutton, Imre. Indian Land Tenure: Bibliographical Essays and a Guide to the Literature. New York: Clearwater Publishing Co., Inc., 1975.

Swan, James G. The Northwest Coast: or, Three Years' Residence in Washington Territory. New York: Harper and Brothers, 1857; reprint, Seattle: University of Washington, Press, 1972 .

Taylor, Herbert C. Oregon Indians I: Anthropological Investigation of the Tillamook Indians. New York: Garland Publishing, Inc. 1974.

Teit, James A. "The Salishan Tribes of the Western Plateau." Forty-fifth Annual Report of the Bureau of Ethnology to the secretary of the Smithsonian Institution. 1927-28. pp. 25-777. Washington: Government Printing Office, 1928. 
The Oregonian, and Indian's Advocate, Philadelphia. Vol. 1 , No. 1 .

The Publications of the Hudson's Bay Record Society. Letters Outward 1679-1694. London: HB Rec Soc, 1948.

Thompson, Laurence C. and M. Dale Kinkade. "Languages" Handbook of North American Indians. Washington, D.C.: Smithsonian Institution, 1990.

Thwaites, Reuben Gold, ed. Narrative of a Voyage To the Northwest Coast of America in the Years 1811,1812, 1813, and 1814: or the First American settlement on the Pacific, by Gabriel Franchère. Cleveland: The Arthur H. Clark Company, 1904.

Turnbaugh, William A. "Wide-Area Connections in Native North America" American Indian Culture and Research. $1(4): 22-28$.

United States Congress, Executive Documents, 31st Congress, 1st Session. Vol. 3, part 3, 1849-50.

Unruh, John D., Jr. The Plains Across: The Overland Emigrants and the Trans-Mississippi West, 1840-60. Urbana: University of Illinois Press, 1979.

Waldman, Carl. Atlas of the North American Indian. New York: Facts on File Publications, 1985.

Wallerstein, Immanuel. Historical Capitalism. London: Verso Editions, 1983.

Washburn, Wilcomb E. Handbook of North American Indians, Vol. 4 History of Indian-White Relations. Washington: Smithsonian Institution, 1988.

White, Richard. The Roots of Dependency. Lincoln: University of Nebraska Press, 1983. 
Wisner, Rev. Benjamin B. "The Proper Mode of Conducting Missions to the Heathens," The Missionary Herald 26 (1830.) 